\title{
Selenium mobility in a major Chalk aquifer (Lille metropolis, northern France): contaminants cycles driven by geology, redox processes and pumping
}

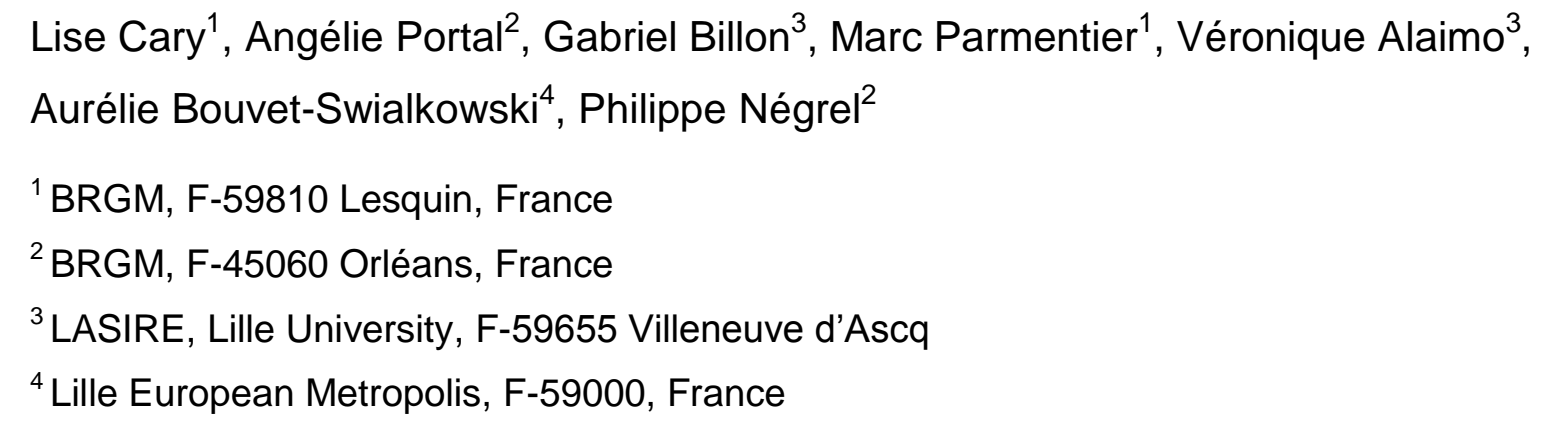

\section{Abstract}

Chalk groundwater in northern France presents selenium (Se) concentrations from $<10$ to $70 \mu \mathrm{g} \mathrm{L}^{-1}$, partly exceeding the latest European Framework Directive's drinking-water limit value of $20 \mu \mathrm{g} \mathrm{L}^{-1}$. Better to understand the heterogeneous dynamics of Se, we used a combination of geochemical, isotopic and geophysical tools on a study site belonging to the Metropolis of Lille, France. This approach provided a fine understanding of the Se fate in a dynamic redox system constrained by geology, related redox processes and pumping, illustrating how local versus global controls affect the Se cycling. A remarkable redox sequence controls element transfers in groundwater with a progressive creation of reductive conditions. Highlighted by geophysical tools, a wide fracture corridor in the Chalk formation disrupts the geological setting of this redox sequence. Under pumping, this corridor allows the mixing of oxygenated groundwater with groundwater under reducing conditions. The evolution of isotopic compositions of sulphate molecules confirms the global reduction trend of sulphates, while pyrite oxidation occurs very locally, together with high Se concentrations. Pyrite is expected to play a predominant role in Se mobility in the Chalk aquifer. Se and other redox sensitive elements ( $\mathrm{Fe}, \mathrm{Mn}, \mathrm{N}$ and $\mathrm{S}$ ) undergo multiple redox cycles, resulting in a Se-rich redox front that migrates downward over time within the water-level fluctuation zone of the porous Chalk. With the decreasing trend of water levels caused by global changes, a Se stock could be immobilized in the unsaturated zone, but nitrate content and redox conditions in the saturated zone will be major drivers for Se mobility.

\section{Introduction}

Selenium (Se)—a non-metallic element of nutritional and toxicological importance-has been intensively studied in terms of biological effects and environmental concern, notably because 
of its Janus-faced properties (toxicity vs. antioxidant, mutagenic vs. anti-mutagenic) that are highly dependent on its concentration and speciation (Brozmanová et al., 2010; Rayman, 2000; Vinceti et al., 2013). Se mobility, toxicity, bioavailability and bioaccumulation are linked to its speciation, and are controlled by sorption and redox reactions (Sharma et al., 2014). Se occurs in various oxidation states (VI, IV, $0,-\mathrm{II})$, as inorganic species and as organo-Se complexes. The most common Se species within surface water, groundwater and soil are selenate $\left(\mathrm{Se}(\mathrm{VI}), \mathrm{SeO}_{4}{ }^{2-}\right)$ and selenite $\left(\mathrm{Se}(\mathrm{IV}), \mathrm{SeO}_{3}{ }^{2-}\right)$ oxyanions that are highly soluble, though $\mathrm{Se}(\mathrm{IV})$ adsorbs to solids more strongly at neutral $\mathrm{pH}$ (Neal and Sposito, 1989). $\mathrm{SeO}_{4}{ }^{2-}$ with the highest oxidation state can be chemically reduced to $\mathrm{SeO}_{3}$, which can be further reduced to elemental $\mathrm{Se}(0)$ or selenomethionine (SeMet) that may then be volatilized as dimethyl selenium (DMSe). Selenium intake through drinking water occurs mainly in its inorganic form that is generally more toxic than organic compounds, $\mathrm{Se}(\mathrm{VI})$ being the most toxic species (Tugarova et al., 2013).

Excess Se levels in agricultural soil or within subsurface agricultural drainage- and ground-waters have caused severe health problems in animals and humans, e.g. in the United States (Ohlendorf and Santolo, 1994), China (Yang et al., 1983) or India (Bajaj et al., 2011; Dhillon and Dhillon, 1991)... Se occurs naturally as a trace element in geologic formations, mainly shale, e.g., (Kulp and Pratt, 2004; Mast et al., 2014; Parnell et al., 2016; Stillings and Amacher, 2010; Tuttle et al., 2014), conglomerates (Dhillon and Dhillon, 2014), coal (Liu et al., 2013) and sediments (Beisner et al., 2009; Cary et al., 2014; Masscheleyn et al., 1991).

The general increase in water demand, and the change in amounts and periods of natural recharge in the current times of global climate change, modify groundwater levels and saturation conditions of Earth's critical zone and thereby the biogeochemical cycle of chemicals like Se (Mitchell et al., 2012). The result is the risk of delivering water that does not comply with drinking water standards. For the purpose of health control, the recent version of the European Water Framework Directive WFD (2020/2184) has increased the Se threshold value for human consumption to $20 \mu \mathrm{g} \mathrm{L}^{-1}$, compared to $10 \mu \mathrm{g} \mathrm{L}^{-1}$ in the initial WFD 
61 (2000/60/EC). An increase up to $30 \mu \mathrm{g} \mathrm{L}^{-1}$ can be accepted if a natural origin of Se is shown, although a reassessment of a safe upper limit of Se of $1 \mu \mathrm{g} \mathrm{L}^{-1}$ in drinking water is recommended as toxic effects of Se species occur at low concentrations (Barron et al., 2009; Vinceti et al., 2013).

Redox processes in groundwater are complex because they are linked to kinetics and to a microbially activated network of reactions ; contaminant fate in redox-dynamic systems thus needs specific studies (Borch et al., 2010). Selenium oxyanions can be microbially reduced via dissimilatory reduction processes mainly to insoluble elemental $\mathrm{Se}(0)$ (Oremland et al., 1989), which can be further reduced to selenide, Se(-II) (Fernández-Martínez and Charlet, 2009; Herbel et al., 2003; Séby et al., 1997). Under reducing conditions, Se(0) and Se(-II) become the dominant species (Zhang and Moore, 1996). Microorganisms can also produce volatile Se-methyl forms and Se-II organic compounds (Chasteen and Bentley, 2003).

Bacterial respiration will transfer electrons from an energy source (organic matter or minerals such as $\mathrm{FeS}_{2}$ ), termed electron donor, to oxygenated species or electron acceptors like dissolved dioxygen $\left(\mathrm{O}_{2}\right)$, nitrate $\left(\mathrm{NO}_{3}{ }^{-}\right)$, or selenate $\mathrm{Se}(\mathrm{VI}), \mathrm{Mn}(\mathrm{IV}), \mathrm{Fe}(\mathrm{III})$, and sulphate $\left(\mathrm{SO}_{4}{ }^{2-}\right)$ (Bailey, 2016). In groundwater, the chemical reduction of $\mathrm{SeO}_{4}{ }^{2-}$ to $\mathrm{SeO}_{3}{ }^{2-}$ occurs after reduction of $\mathrm{O}_{2}$ and $\mathrm{NO}_{3}^{-}$. Abiotic redox reactions also play an important role in Se cycling (Breynaert et al., 2008). A variety of $\mathrm{Fe}(\mathrm{II})$-bearing minerals can enhance abiotical Se(IV) or $\mathrm{Se}(\mathrm{VI})$ reduction to $\mathrm{Se}(0)$, such as green rust, pyrite or mackinawite (Breynaert et al., 2008; Kang et al., 2011; Schellenger and Larese-Casanova, 2013). However, little is known about the Se oxidation. Under aerobic conditions, microbial oxidation promote both Se volatilization, retention (Darcheville et al., 2008) and production of $\mathrm{Se}(\mathrm{VI})$ from $\mathrm{Se}(0)$ (Dowdle and Oremland, 1998). The oxidation of Se-bearing pyrite by $\mathrm{O}_{2}$ or $\mathrm{NO}_{3}$ releases $\mathrm{Se}(\mathrm{VI})$ into groundwater (Stillings and Amacher, 2010). Finally, Se(IV) sorbe more than $\mathrm{Se}(\mathrm{VI})$ onto organic matter, clay, iron oxides and iron sulphides (Coppin et al., 2009; Goldberg et al., 2007). 
Earlier, we studied the spatial disparities in $\mathrm{Sr}$ isotopic signatures, and $\mathrm{Sr}$ and $\mathrm{Se}$ contents in the Chalk aquifer along the northern edge of the Paris Basin (France) to successfully identify Se origins in the aquifer (Cary et al., 2014). The present study focuses on the redox processes affecting Se dynamics in the same Chalk aquifer. Because the largescale evolution of surficial systems can be controlled by very localized biogeochemical processes, we propose a multi-scale and interdisciplinary characterization, from bedrock to aquifer. Geophysical imaging and solid analysis documented the spatial geological heterogeneities. The processes affecting groundwater chemistry were assessed along with monitoring of the wells, and the analysis of $\delta^{34} S$ and $\delta^{18} \mathrm{O}$ of sulphate. This approach led to a fine understanding of the Se cycle, constrained by the geology of the Chalk aquifer of Northern France and by related redox processes as well as by pumping, illustrating how it is controlled either by both local and global constraints.

\section{Geological and hydrogeological context}

The north of France is part of the northern margin of the Paris Basin, one of the main geological units of Western Europe. Local outcrops range from Late Cretaceous to the Quaternary (Figure Fig. 1). The "Dièves" clayey marls of Early and Middle Turonian age are up to $70 \mathrm{~m}$ thick. The overlying Senonian-Turonian white Chalk is up to $70 \mathrm{~m}$ thick. Above, local Tertiary deposits are composed of Louvil clays (Early Thanetian; 9-12 m thick), the Ostricourt sands (Late Thanetian; $>30$ m thick locally) and the Orchies or Flandres clays (Early Ypresian; 10-15 m thick). The Quaternary silt covers all Meso-Cenozoic formations. In the Deûle valley, the modern alluvial deposits are sand, clay and clayey sand, and locally peat layers and gravel beds. The alluvium is 2 to $5 \mathrm{~m}$ thick in the study region. With the "Dièves" as the impermeable base, the upper part of the white Chalk corresponds to the aquifer exploited in the wellfields in the south of Lille Metropolis. Groundwater flows in the Chalk aquifer through a network of faults and open fissures that is well developed at $10-20 \mathrm{~m}$ depth, and where the main water inflow occurs (Walaszek et al., 2021). From 1981 to 2010, 
114 the average annual rainfall was $742 \mathrm{~mm}$ with an effective rainfall of $186 \mathrm{~mm}(25 \%)$, the main 115 recharge area being close to Emmerin.

116 About $30 \%$ of the drinking and tap waters for Lille Metropolis is pumped from four main 117 well fields tapping the Chalk aquifer southwest of Lille: Emmerin, Houplin-Ancoisne, Les 118 Ansereuilles and Seclin (Fig. 1). The Emmerin and Houplin-Ancoisne well fields will be 119 referenced hereafter as E-HA, but here we mainly focus on the Les Ansereuilles well field 120 with 26 pumping wells, which is parallel to the Deûle canal. The groundwater, which is 121 unconfined southwest of the Deûle, flows northwest to become confined under the alluvial 122 cover. The A10-A15 well area (Fig. 1) evolves towards local confinement due to the 123 presence of more than $10 \mathrm{~m}$ of Tertiary Louvil clays over the Chalk (Cary et al., 2014).

124 The water levels in the study area vary according to pumping and recharge (Fig. 2). 125 The main water direction flows from NE to SW (well A15 to A10). However, there may be, 126 very locally, another flow direction from well A13 towards well A15 as already observed in a 127 hydrodynamic model based on extraction volumes (Bessière et al., 2015) due to high 128 exploitation rates in well A15. The flow in the fractured corridor between $A 12$ and $A 13$ is 129 unknown. 


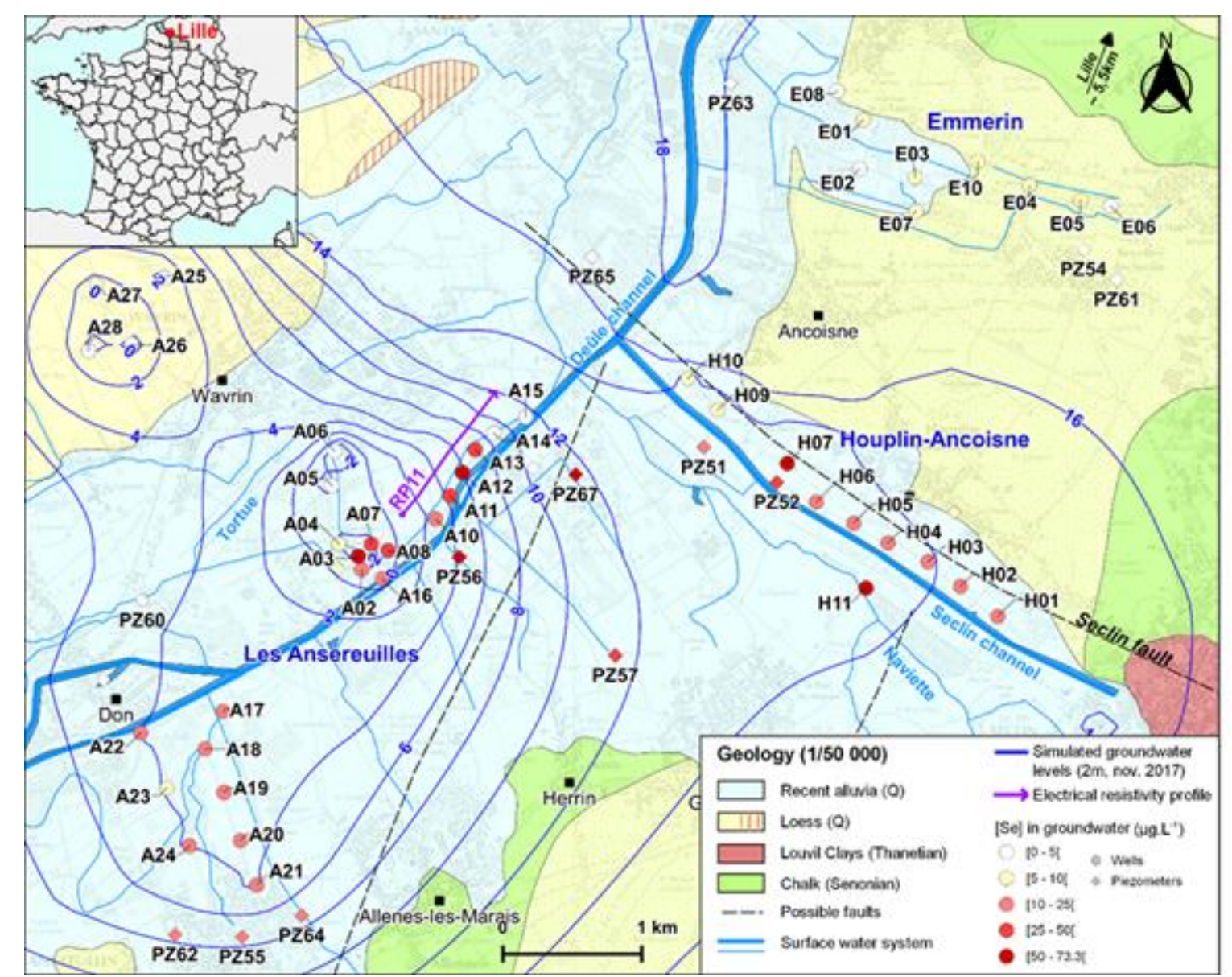

Figure 1: Study site and cross section (RP11) in the well fields of southern Lille. The colour of the pumping wells indicates the maximum concentration of selenium in groundwaters from 2013 to 2017. The piezometric map presents simulated levels with the hydrogeological model.

\section{Material and methods}

\subsection{Solids analysis}

137 Solids were sampled in the Templeuve quarry near the study site and also in a borehole 138 close to well A13. The samples were ground and dissolved chemically (aqua regia $+\mathrm{HF}$ ), and the concentrations were analysed by Inductively Coupled Plasma Mass Spectrometry

140 (ICP-MS) at BRGM. An extraction sequence with chemicals was used for determining the Se

141 content in pyrite and the degree of pyritization of Se, based on the work of (Huerta-Diaz and 142 Morse, 1990): $2.5 \mathrm{~g}$ of sediment was placed in contact with a $1 \mathrm{M} \mathrm{HCl}$ solution to extract the 143 so-called reactive fraction for 24 hours at room temperature. Though this reactive fraction is 
144 generally accepted by the scientific community for divalent metals, it is, however, only 145 indirectly admitted for Se (Peters et al., 1997; Sharma et al., 2014).

146 After centrifugation, the supernatant was recovered for iron and selenium analyses and 147 the solid was again washed with a $10 \mathrm{M}$ HF solution at room temperature for 24 hours. This 148 washing step was proposed by Huerta-Diaz and Morse (1990) in order to remove elements 149 that are associated to silicates and alumino-silicates before pyrite extraction. Indeed, 150 concentrated nitric acid used to dissolve pyrite may also result in partial extraction of some 151 elements from silicate phases. It is worth noted that this step is not considered here as a 152 specific extraction and the recovery solution was therefore not analysed. The solid recovered 153 was rinsed with Milli-Q water and finally put in contact with concentrated $\mathrm{HNO}_{3}$ for 2 hours at room temperature. During this step, the pyrite was solubilized and the selenium extracted. Fe 155 and S were then determined by ICP-AES (Agilent, model 5110 VDV) to quantify the pyrite 156 content and to check that the Fe/S molar ratio was 0.5 . Se was determined by ICP-MS 157 (Agilent, model 7900) using a collision-reaction chamber under hydrogen flow and by 158 targeting the ${ }^{78} \mathrm{Se}$ isotope. From these extractions, it was possible to calculate the degree of 159 pyritization (DOP, Equation 1) and the degree of trace selenium pyritization (DTSeP, 160 Equation 2) as follows (Huerta-Diaz and Morse, 1990):

161

162

163 164 165 166 167 168

$$
\begin{gathered}
D O P=[\mathrm{Fe}]_{\text {pyrite }} /\left([\mathrm{Fe}]_{\text {pyrite }}+[\mathrm{Fe}]_{\mathrm{HCl}}\right)(\mathrm{Eq} .1) \\
D T S e P=[\mathrm{Se}]_{\text {pyrite }} /\left([\mathrm{Se}]_{\text {pyrite }}+[\mathrm{Se}]_{\mathrm{HCl}}\right)(\mathrm{Eq} .2)
\end{gathered}
$$

\subsection{Water analyses}

The initial sampling and analysis work (June 2011 to March 2013) concerned 20 wells as described in Cary et al. (2014). Although a complete chemistry analysis was conducted, only selected data are presented here. Measurements of the physical and chemical parameters (temperature, conductivity, $\mathrm{pH}$, Eh ( $\mathrm{Pt} / \mathrm{Ag} \mathrm{AgCl})$, and dissolved oxygen) were made in situ. The groundwater samples were then filtered in the field at $0.45 \mu \mathrm{m}$. In the sample sets, the $S$ and $\mathrm{Se}$ speciation were determined, with concentrations of total $\mathrm{S}, \mathrm{S}_{2} \mathrm{O}_{3}, \mathrm{~S}^{2-}, \mathrm{SO}_{3}$, total $\mathrm{Se}$, 
$171 \mathrm{Se}(\mathrm{VI})$ and $\mathrm{Se}(\mathrm{IV})$ being measured by HPLC-ICP-MS after separation. Dissolved Fe(II) was 172 analysed in the field by colorimetry. Dosage of total organic carbon (TOC) and dissolved 173 organic carbon (DOC) was carried out on the raw solution after oxidation with sodium 174 persulphate in a hot acid medium. The $\delta^{34} S$ and $\delta^{18} \mathrm{O}$ of the sulphate were analysed on raw water. The $\square^{34} \mathrm{~S}$ of sulphates was measured from $\mathrm{SO}_{2}$ obtained from CdS precipitate after

$176 \mathrm{SO}_{4}$ reduction with addition of cadmium acetate. $\mathrm{S}$ and $\mathrm{O}$ isotopic compositions were 177 determined on $\mathrm{SO}_{4}$ using a Delta $\mathrm{S}$ mass spectrometer (Thermo Finnigan) with a precision of $1780.3 \%$. Isotopic compositions use the usual $\delta$-scale in $\%$ occording to $\delta_{\text {sample }}(\%)=\left(R_{\text {sample }}{ }^{-}\right.$ $179 R_{\text {standard }} / R_{\text {standard }}{ }^{*} 1000$, where $R$ is the ${ }^{34} S /{ }^{32} S$ atom ratio, from V-CDT (Vienna - Canyon 180 Diablo Troilite) isotope ratio standards.

The second campaign took place in November 2017, with sampling and water analysis

182 for chemistry, $\square{ }^{13} \mathrm{C}_{\mathrm{CID}}$, and gas sampling and analysis. Total $\mathrm{DOC}$ was extracted as $\mathrm{CO}_{2}$ by

183 water sample acidification with $\mathrm{H}_{3} \mathrm{PO}_{4}$. The $\mathrm{CO}_{2}$ extracted under vacuum was purified before 184 analysis by mass spectrometry. Results are given in $\square{ }^{13} \mathrm{C}_{\mathrm{TDIC}}$ vs. PDB (in \%o). Gases were 185 analysed by the BRGM laboratory using a Trace GC Ultra Thermo Fisher Scientific gas 186 chromatograph (Thermo Scientific, with FID detector). The gases investigated were $\mathrm{CO}_{2}, \mathrm{H}_{2}$, $187 \mathrm{O}_{2}, \mathrm{~N}_{2}, \mathrm{H}_{2} \mathrm{~S}, \mathrm{CH}_{4}$ with injection valves of $25 \mu \mathrm{L}$ and $250 \mu \mathrm{L}$. Detection limits were $0.001 \%$ 188 (v/v) for $\mathrm{CO}_{2}, \mathrm{O}_{2}$ and $\mathrm{N}_{2}, 0.005 \%(\mathrm{v} / \mathrm{v})$ for $\mathrm{H}_{2}$ and $\mathrm{H}_{2} \mathrm{~S}$, and $0.0002 \%(\mathrm{v} / \mathrm{v})$ for $\mathrm{CH}_{4}$. Finally, available chemical data of the Lille Metropolis were taken from the trimestrial water-quality surveys (2013 to 2017), which only present total Se concentrations.

\subsection{Geophysical imaging}

192 Knowledge of the complex organization of geological formations, such as the presence of 193 clays that can induce groundwater confinement and thus the modification of the redox conditions controlling the mobility of selenium, or the fracturing of the chalk that can induce

195 preferential water circulations, is an essential lock. To image the subsurface, we used 196 geophysics, and in particular electrical resistivity tomography. The applied Direct-Current 
resistivity method, imaging the resistivity distribution in the subsurface, is widely used for hydrogeological purposes (Revil et al., 2012) and references therein).

A 2-D resistivity profile (RP) was measured in August 2019 about $200 \mathrm{~m}$ to the northwest of the Ansereuilles well field, from well A10 to well A15 (RP11, Fig. 1). For data acquisition, a multi-electrode Syscal Pro Switch system (IRIS Instruments) was connected to 96 stainless electrodes $5 \mathrm{~m}$ apart. Both dipole-dipole and reciprocal Wenner-Schlumberger arrays were considered; the former for its good resolution of surface levels and lateral resistivity variations, the latter for its sensitivity to vertical resistivity variations that clearly identify horizontal geological levels (Loke, 2015). After data filtering $\left(V_{\min } \geq 0.1 \mathrm{mV}, I_{\min } \geq 20 \mathrm{~mA}, \mathrm{Q}\right.$ $\leq 5 \%$ ), the electrode topography was incorporated. The Chalk roof and Dièves roof interfaces from the 3-D geological model of the study area (Picot and Bourgine, 2010) were also included to improve the results. Then, a robust-type inversion with RES2DINV software (ver. 4.10) was run (Loke, 2020). The RMS error of the resulting resistivity section was $5.8 \%$ after five iterations. Interpretation of the 2-D resistivity model was supported by the drilling logs of wells A10 to A15 (BSS, BRGM) and the geological map (Desoignies and Sangnier, 1968).

\section{Results}

\subsection{Geological setting}

For the Quaternary formations, the surface R1 layer (1 to $5 \mathrm{~m}$ thick) is moderately resistive at 30-35 $\Omega \mathrm{m}$ (Fig. 2). Mostly consisting of Quaternary silt (Desoignies and Sangnier, 1968), resistivity values in R1 near the Deûle River (300-350 m) suggest a rather sandy facies.

The underlying conductive $\mathrm{C} 1$ horizon has a resistivity below $20-25 \Omega \mathrm{m}$ and mostly consists of Quaternary alluvium. It is on average $10 \mathrm{~m}$ thick (Desoignies and Sangnier, 1968), but locally varies from 5 to $15 \mathrm{~m}$, according to undulations in the roof of the underlying horizon. Quaternary alluvium mainly is found in the southwest part of the RP11 profile; it is exposed to the northeast and its thickness is difficult to evaluate. Here, C1 lies on the highly conductive $\mathrm{C}^{1}$ ' horizon with an average resistivity below $5 \Omega \mathrm{m}$. According to the 
223 numerous drill logs available along the profile, C1' corresponds to the Louvil Clay (Thanetian, 224 Eocene).

For the Senonian-Turonian Chalk and the Dièves, the C2 layer is moderately resistive, between 25 and $50 \Omega m$ (Fig. 2). Below, the R2 unit shows resistivity values over 50-60 $\Omega \mathrm{m}$. From a lithological viewpoint, both $\mathrm{C} 2$ and R2 units correspond to the Senonian228 Turonian Chalk. Although the roof of the C2 layer is very irregular along the profile, we 229 observed a progressive deepening from SW to NE whose maximum amplitude is about $15 \mathrm{~m}$. Within the $\mathrm{R} 2$ resistive unit, we noted a 60-m-wide area where the resistivity slightly decreases ( $30 \Omega \mathrm{m}, \mathrm{C2}$ ) close to well A13 (abscissae 600 to $660 \mathrm{~m}$ on Fig. 2). Finally, the the resistivity section. Analysis of the drill logs indicates that this layer corresponds to Lower

234 Turonian (Dièves) marl.

235

236

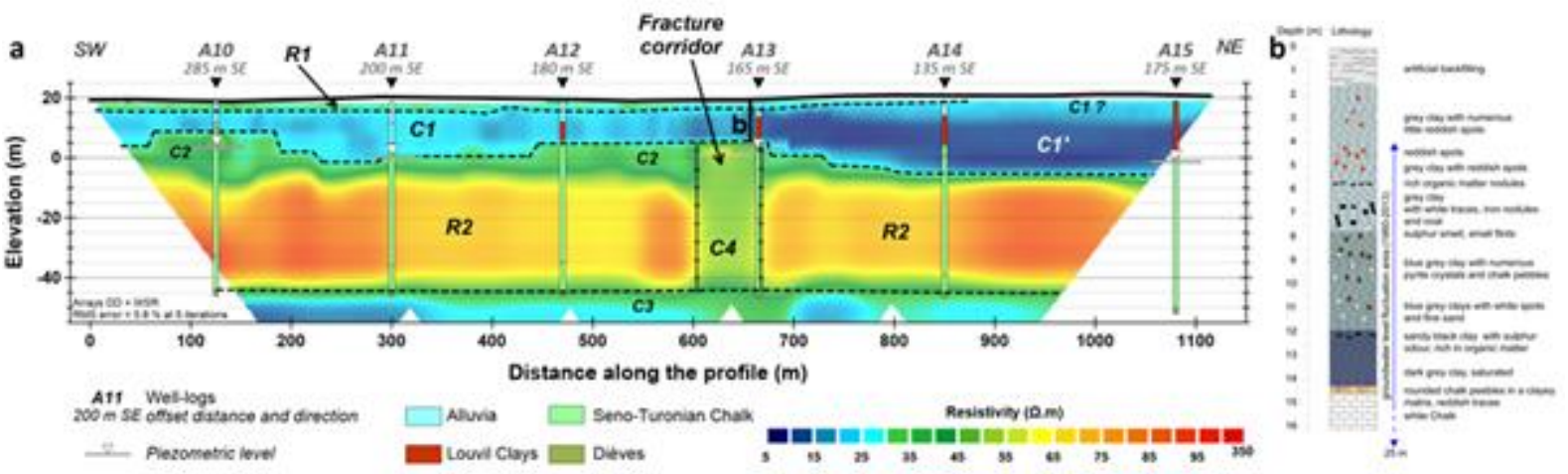

Figure 2: a) 2-D resistivity inversion model along the RP11 profile in Les Ansereuilles well field measured in August 2019, and static water levels measured on 31/08/2019 (see Fig. 1 for the location of the RP profile) ; b) Description of the lithology from a drill log near well A13

\subsection{Selenium in the geological formations}

The Chalk formation of the Templeuve quarry had Se contents below the quantification limit $\left(\mathrm{QL}=1 \mathrm{mg} \mathrm{kg}^{-1}\right)$ whereas the Tertiary and Quaternary formations contained relatively high Se concentrations (Table 1). The highest Se values, 3.57 and $4.87 \mathrm{mg} \mathrm{kg}^{-1}$, were measured in the upper part of the Thanetian Ostricourt Sand and in the Ypresian Orchies Clay, 
246 respectively. Quaternary silt had rather high Se contents $\left(4.1 \mathrm{mg} \mathrm{kg}^{-1}\right)$. Total organic carbon 247 content was $0.27 \%$ in Quaternary silt and $0.5 \%$ in the Ypresian clay. X-ray diffraction (XRD) 248 patterns of the Chalk show over $99 \%$ calcite, traces of quartz $(\sim 1 \%)$ and, in the reddish parts 249 of the Chalk, traces of siderite and possibly hematite. Ypresian clay and the top of the 250 Thanetian sand show XRD patterns indicating a large presence of quartz and illite, together 251 with pyrite.

More locally, the samples at $11.8,13.3$ and $14.2 \mathrm{~m}$ depth of the borehole at well $\mathrm{A} 13$ (Table 1) contain an assemblage of zeolite (7-19\%), smectite (69-84\%) and opal-CT already described in the British Thanetian (Huggett and Knox, 2006) that may be a typical 255 assemblage of this age, confirming the hypothesis that the clay overlying Chalk in Les Ansereuilles is Thanetian Louvil Clay ((Cary et al., 2014). The other minerals in the $<2 \mu \mathrm{m}$ fraction below $11.8 \mathrm{~m}$, are illite $(8-11 \%)$, chlorite (1-2\%) and quartz. The samples contained up to $4.6 \mathrm{mg} \mathrm{kg}^{-1} \mathrm{Se}$ at the bottom of the profile, above the Chalk at $13 \mathrm{~m}$ depth (Table 1 ). High Se levels $\left(4.8 \mathrm{mg} \mathrm{kg}^{-1}\right)$ were also found in the banks around well A13, consisting of ash waste from the old thermal plant. At $8.5 \mathrm{~m}$ depth, solids are enriched in $\mathrm{Fe}(7.5 \%)$, Se $\left(3.9 \mathrm{mg} \mathrm{kg}^{-1}\right)$ and organic matter $(0.54 \%)$.

Pyrite grains, up to $5 \mathrm{~mm}$ large, were found between 7 and $14 \mathrm{~m}$ depth in well $\mathrm{A} 13$.

Both fine-grained and coarser sediments at this depth range contain up to 0.85 wt\% pyrite according to the semi-quantitative XRD patterns. The largest pyrite grains were sampled manually at 7, 8.5 and $8.8 \mathrm{~m}$ depth; after washing the grains with acid solutions (see previous section), the selenium concentration was estimated for nine replicates of different pyrite-grain samples. We found a Se concentration of $1.2 \mathrm{mg} \mathrm{kg}^{-1}$ with an RSD of $22 \%$. In raw sediment, several chemical extractions were needed for understanding the Se distribution, especially as related to pyritic compounds (Table 1, Fig. 2). Se concentrations in 270 pyrite are generally below $0.01 \%$, except in the $A 13$ sample at $5.5 \mathrm{~m}$ depth where the 271 maximum content is observed (1.1\%). Overall, these concentrations are higher than the 272 values measured in well-crystallized pyrite grains. Table 1 shows that a significant fraction of 273 total Se is included in pyrite with values between 6 and 29\% (see Fig. 2 of SI). The DTSeP is 
274 still higher (35-74\%), meaning that the "mobile Se" (defined by the fraction extracted with a

$2751 \mathrm{M} \mathrm{HCl}$ solution) is well trapped in the pyrite fraction (see Fig. 2 of $\mathrm{SI}$ ).

276

277

278

279

280

281

282

283

284

285

286

287

288

289

290

291

292

293

294

295

296

297

298

299

300

301

302
Table 1: Chemical composition (bulk) and mineralogy (bulk and <2 $\mu \mathrm{m}$ fraction) of the regional and local geological formations (sampled at the vicinity of well A13).

\subsection{Spatial and temporal variability of groundwater chemistry}

The results are presented in Table 2 and on Figs 3 and 4, the sampling points being shown on Fig. 1. Groundwater displayed pH varying from 6.8 (well A4) to 7.3 (well A24). The redox potential varied from $177 \mathrm{mV}$ (well A26) to $460 \mathrm{mV}$ (well E5, Emmerin). The physical and chemical parameters of the groundwater showed a significant spatial variability. The E$\mathrm{HA}$ groundwater had low $\mathrm{SO}_{4}{ }^{2-}$ and high $\mathrm{NO}_{3}{ }^{-}$concentrations, but the groundwater of the confined end-member (wells A25 to A28) stood out in having high $\mathrm{Cl}$ and $\mathrm{SO}_{4}{ }^{2-}$ concentrations. Comparatively, the groundwater in wells $\mathrm{A} 12$ and $\mathrm{A} 13$ had high $\mathrm{SO}_{4}{ }^{2-}$ and low $\mathrm{NO}_{3}{ }^{-}$concentrations. For each point, time variations are represented by the range of values in Figs 3 and 4; they are best expressed for Se values in the wells of the redox sequence, where Se contents can double during a year.

For $\mathrm{S}$ speciation, $\mathrm{S}^{2-}$ and $\mathrm{S}_{2} \mathrm{O}_{3}{ }^{2-}$ were measured $<\mathrm{QL}$, whereas low amounts of $\mathrm{SO}_{3}{ }^{2-}$ were found in most groundwater samples (not shown in Table 2). For Se speciation, all groundwater samples had $\mathrm{Se}(\mathrm{VI})$ concentrations at levels over the QL. Only the groundwater in wells $\mathrm{A} 12$ and $\mathrm{A} 13$ had low amounts of $\mathrm{Se}(\mathrm{IV})\left(0.27-1.39 \mu \mathrm{g} \mathrm{L} \mathrm{L}^{-1}\right), \mathrm{Se}(\mathrm{VI})$ being the major aqueous phase. Table 3 shows dissolved gas values in 7 wells of the redox sequence and three wells of the catchment. Methane is present in increasing concentrations from wells A12 to $A 15$, but absent elsewhere. Well $A 13$ contains clear peaks of $\mathrm{CO}_{2}$ and $\mathrm{O}_{2}$, but less $\mathrm{N}_{2}$ than in the other wells.

Table 2: Physical and chemical composition of groundwater samples from 2011 to 2019. DO is dissolved oxygen. TOC is for Total Organic Carbon. The precision is $\pm 0.3 \%$ on $\delta^{18} \mathrm{O}_{S O 4}$ and $\delta^{34} S_{S O 4}$ and $0.1 \mu \mathrm{gL}^{-1}$ on $\mathrm{Se}(\mathrm{VI})$ and $\mathrm{Se}(\mathrm{IV})$. 
305 The Emmerin groundwaters have positive isotopic compositions for $\delta^{34} S$ and $\delta^{18} \mathrm{O}$ of 306 sulphate, whereas all other groundwaters show negative $\delta^{34} S$ (Table 2). Houplin-Ancoisne 307 groundwaters show a high variability of $\delta^{34} S(-30$ to $-5 \%$ including error bars $)$ and $\delta^{18} \mathrm{O}(0$ to $3086 \%$ ) during the whole monitoring year, similar to those observed in the Les Ansereuilles well 309 field that shows $\delta^{34} S$ varying from $-27.4 \%$ (A12) to $-5.7 \%$ (A23). Monthly monitoring of well A13 showed a stable $\delta^{34} S\left(\delta^{34} S\right.$ close to $-20 \%$ ) and $\delta^{18} \mathrm{O}$ variations (around 6\%). A decrease of $\delta^{18} \mathrm{O}$ values occurred in groundwater from February to May, followed by an increase until next winter with the highest $\delta^{18} \mathrm{O}$ in February-March, back to the initial values.

\section{Discussion}

\subsection{Geophysics and hydrogeology}

The geophysical results highlight two essential elements from a hydrogeological point of 316 view. First, they confirm the presence of Louvil Clays (C1') and define their geometry (Fig 2). 317 To the southwest, these clays are lenticular within recent alluvial deposits (C1) and evolve 318 into a continuous level to the northeast, thanks to a deepening of the underlying horizon. The 319 transition between Quaternary alluvium and Louvil Clays is progressive, and we cannot define a precise limit between those two units. This thickening of the Louvil Clays leads to a progressive confinement of the Chalk aquifer from southwest to northeast.

Beyond the $600 \mathrm{~m}$ abscissa, the Louvil Clays are 7 to $15 \mathrm{~m}$ thick according to the well logs (A13, A14 and A15, Fig. 2), but the thickness of the corresponding C1' electrical horizon varies from $10 \mathrm{~m}(\mathrm{~A} 13)$ to about $20 \mathrm{~m}$ (A14, A15). The upper conductive part of the Chalk (C2) corresponds to its weathering-related fractured and productive part (Portal et al., submitted). Starting at well A13, we suggest that the very low resistivities in the upper part of the Chalk are due to the presence of Louvil clay that may have infiltrated the underlying Chalk and settled along the walls of the macro- and microporosity. This clay coating could 
explain the low resistivities observed for weathered Chalk in this area. It also has strong hydrogeological consequences, as it contributes to increasing water-residence time and thus enhances water-rock interactions.

Secondly, geophysics show a local resistivity decrease (C2') into the resistive Chalk (R2, Fig. 2). We interpret this 60-m-wide area as a large fracture corridor. Such structures are well known in basement contexts (Acworth, 1987) and their more conductive signature, compared to that of fresh basement rock, had already been observed (Belle et al., 2019; Comte et al., 2012; Descloitres et al., 2008). To our knowledge, few other geophysical studies have focused on the Chalk aquifer, probably because it is an easily exploitable water resource. However, recent work on the hydrogeological setting of the Chalk aquifer in Normandy (France) has highlighted similar multi-decametric zones of resistivity decrease within the resistive Chalk, related to regional or local faults (Meire et al., 2019; Portal et al.,

341 2020). The geophysical anomaly identified close to well A13 may result from alteration due to 342 the presence of faults. It probably extends on either side of the RP11 profile, following a $343 \mathrm{~N} 110-\mathrm{N} 130$ orientation inherited from the regional trend of Carboniferous basement tectonic 344 structures, thus constituting a preferential groundwater circulation pathway that may favour the mixing of groundwaters of different origins under the impulse of pumping.

\subsection{Se contents in rock}

347 The geological units of the northern region show heterogeneous Se contents, comparable to 348 those of the formations of the whole Paris Basin (Table 1). Whereas Ypresian clay commonly 349 has the highest Se concentrations of Paris Basin sediments (695 mg kg ${ }^{-1}$ in Lower Ypresian 350 lignitic Black Sands, $11.8 \mathrm{mg} \mathrm{kg}^{-1}$ in Lower Ypresian Clay (Gourcy et al., 2011), the Se 351 contents of the Tertiary and Quaternary formations in the Lille region are much lower (4.6-4.9 $352 \mathrm{mg} \mathrm{kg}{ }^{-1}$ ). Moreover, the highest Se values of the study area are found in basal Thanetian 353 Louvil Clays overlying the Chalk (4-4.6 mg kg-1). The Se content of Quaternary silt in the Lille 354 region is clearly higher than that observed in agricultural soil developed on Quaternary 355 deposits in Belgium, ranging from 0.1 to $0.7 \mathrm{mg} \mathrm{kg}^{-1}$ (De Temmerman et al., 2014). Overall, 
356 the soils of northern France and Belgium are known to be Se-depleted, the Se being 357 supplied by Se-rich mineral fertilizers, containing up to $200 \mathrm{mg} \mathrm{kg}^{-1} \mathrm{Se}$, as well as animal 358 manure (ADEME, 2007) to ensure correct Se contents in wheat.

359 The "primary" presence of Se is indeed linked to Quaternary deposits when present 360 (e.g., aerial loess vs. erosion of Tertiary Se-enriched sediments), and local 'hot spots' of Se361 enriched soil reaching $1 \mathrm{mg} \mathrm{kg}^{-1}$ are known in the north-eastern part of the Paris Basin 362 including the Lille region (Baize et al., 2010). Generally speaking, the Se content of bedrock 363 and soil in the Lille region is comparable to that of other Se-rich geological regions in the 364 world and can present Se values over $1 \mathrm{mg} \mathrm{kg}^{-1}$, which is considered as the toxic level 365 (Bailey, 2016). The processes leading to high Se concentrations in groundwater thus remain 366 to be understood.

\subsection{The local Chalk groundwater chemistry}

368 The chemical facies of the groundwater samples are bicarbonate-calcium type (Ca-Mg$369 \mathrm{HCO}_{3}$, see Piper diagram in Fig. 1 in Supporting Information) and evolve between two facies 370 (Fig 3): (1) the upstream oxic E-HA groundwater type where dissolved $\mathrm{O}_{2}$ varies from 4.8 to $3718.9 \mathrm{mg} \mathrm{L}^{-1}$, with high $\mathrm{NO}_{3}$ and low sulphate concentrations; and (2) the confined type with semi-oxic groundwater of well A26 under continuous Tertiary cover, with a very low $\mathrm{O}_{2}$

373 content $\left(0.3 \mathrm{mg} \mathrm{L}^{-1}\right)$, a nitrate content $<\mathrm{QL}$ and high sulphate concentrations indicating 374 denitrification and a long residence time with long water-rock interaction (Cary et al., 2014). 375 The $\mathrm{pH}$ range is similar to that in other parts of the unconfined Chalk aquifer in France and 376 England (Edmunds et al., 1987; Négrel and Petelet-Giraud, 2005). $\mathrm{HCO}_{3}$ contents vary between 256 and $506 \mathrm{mg} \mathrm{L}^{-1}$, the lowest values occurring in the

378 Emmerin well field and the highest in well A13 (Table 2). These values are above the usual 379 ones in the English Chalk aquifer (Edmunds et al., 2003), in the Somme region (Négrel and

380 Petelet-Giraud, 2005), or in the south of the Paris Basin (Brenot et al., 2008). Similarly, 381 sulphate concentrations in the study site are all above the ones measured in the Chalk 382 aquifer in the Somme (Négrel and Petelet-Giraud, 2005; Fig. 3). The sulphate content in 
383 wells $\mathrm{A} 12$ and $\mathrm{A} 13$ is higher than the threshold value in English Chalk (Edmunds et al., 384 2003).

385 Compared to the general trend in the Chalk aquifer in France and the UK, the higher 386 mineralization in the Lille region probably originates from exchange with the underlying 387 Carboniferous aquifer and/or the overlying Tertiary sediments. Here, at around $100 \mathrm{~m}$ depth 388 below the Chalk in the studied well fields, the Carboniferous contains Visean evaporites and 389 its groundwater is highly mineralized (Bernard et al., 1981). Upwelling of mineralized fluids 390 may occur through deep-seated faults in the basement and Chalk, particularly near the study 391 site, but this hypothesis has not yet been proven. However, the role of Tertiary sands and 392 clays as sources of mineralization of the Chalk aquifer (Bernard, 1979) is coherent with the 393 high $\mathrm{K}\left(>15 \mathrm{mg} \mathrm{L}^{-1}\right)$ and $\mathrm{SO}_{4}\left(>100 \mathrm{mg} \mathrm{L}^{-1}\right)$ values observed in wells tapping the confined 394 Chalk (wells A25 to A28, Fig. 3 and Table 2). Interestingly, in spite of the reductive conditions 395 in this confined part of the aquifer and sufficient available organic carbon $\left(1.35 \mathrm{mg} \mathrm{L}^{-1}\right), \mathrm{SO}_{4}{ }^{2-}$ 396 remains present in groundwater. 

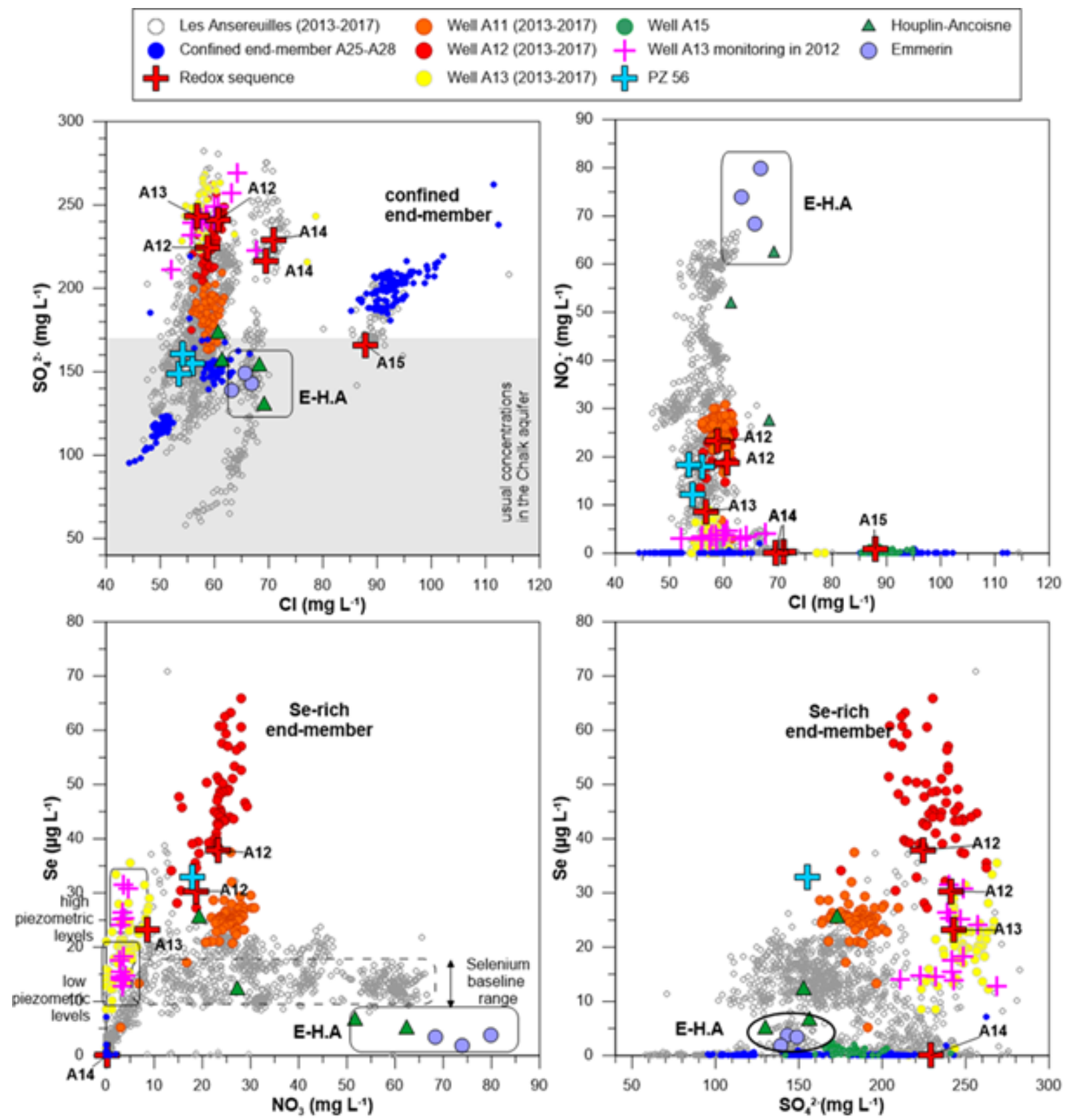

Figure 3: Binary diagrams showings element concentrations in the groundwater of the Chalk aquifer at the study site. All circles are from the quality monitoring of the EML from 2013 to 2017; all other points were acquired in 2011- 2013 and 2017-2019.

\subsection{Geochemical processes of the redox sequence}

403 The continuum of wells A16-A11-A12-A13-A14-A15 along the Deûle channel constitutes a 404 remarkable redox sequence (Fig. 4) over a very short distance (1600 m). Plotting data 405 chronicles from Lille Metropolis for 2013-2017 and recent monitoring studies, shows that the range of concentrations of each parameter is large as it varies with time under the 
407 constraints of natural recharge and pumping. The general transition from oxic to anoxic 408 conditions, driven by clay overlying the Chalk, is rapid but progressive, and the increase in 409 reductive conditions strictly respects the sequence of microbially mediated oxidation410 reduction reactions. Thus increase represents the thermodynamic order of the reactions

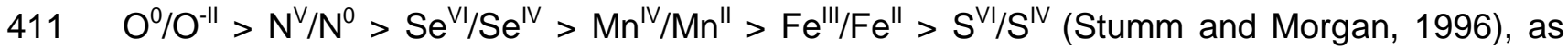
412 already described from England (Edmunds et al., 1987). The measured $\mathrm{O}_{2}$-content range is 413 typically included in the respiration threshold $\left(0.03-2.0 \mathrm{mg} \mathrm{L}^{-1}\right)$, indicating a transition state 414 between the oxidation of organic matter by oxygen and by nitrate (Ashok and Subrata, 2015). 415 Confined conditions cause very low $\mathrm{O}_{2}$ content $\left(0.26\right.$ to $0.50 \mathrm{mg} \mathrm{L}^{-1}$, Fig. 4$)$ and nitrate tends 416 to be reduced (from $25-30 \mathrm{mg} \mathrm{L}^{-1}$ in $\mathrm{A} 16$ to $<\mathrm{QL}$ in $\mathrm{A} 14$ and $\mathrm{A} 15$ ) with the production of $\mathrm{NH}_{4}$ 417 (mean of $0.55 \mathrm{mg} \mathrm{L}^{-1}$ in well A14) and traces of $\mathrm{NO}_{2}^{-}$(Fig. 4). Reduction of nitrate can be 418 associated with oxidation of organic matter, but also with oxidation of reduced minerals 419 (Parmentier et al., 2014), as pyrite was identified in Thanetian clay. Organic carbon is 420 present in the clayey sediment $(0.35-1.80 \% \mathrm{dw})$ overlying the Chalk, and also occurs in 421 aqueous phase in well $\mathrm{A} 13\left(1.5\right.$ to $\left.3.2 \mathrm{mg} \mathrm{L}^{-1}\right)$. Assuming that this organic matter is 422 bioavailable for bacterial metabolism, its oxidation produces inorganic carbon according to 423 the reaction given in Equation 3:

$$
4 \mathrm{NO}_{3}^{-}+5 \mathrm{CH}_{2} \mathrm{O} \rightarrow 2 \mathrm{~N}_{2}+4 \mathrm{HCO}_{3}^{-}+\mathrm{H}_{2} \mathrm{CO}_{3}+2 \mathrm{H}_{2} \mathrm{O} \text { (Eq. 3) }
$$

The organic matter was modelled as $\mathrm{CH}_{2} \mathrm{O}$, although natural organic matter can exhibit different formulae; the resulting production of protons should be different. The production of $\mathrm{N}_{2}$ is proven with high values in wells $\mathrm{A} 12$ and $\mathrm{A} 13$ (1.3 and $1.4 \mathrm{mmol} \mathrm{L}^{-1}$, respectively, Table 3), which are higher than those of E-HA, except for well H11. A denitrification process as in Equation 3 typically goes through a temporary production stage of $\mathrm{NO}_{2}^{-}$and leading to the 430 final production of $\mathrm{NH}_{4}^{+}$, both of which have been identified in groundwater samples. 431 Oxidation of organic matter acidifies the system, but no notable acidification was found in 432 well $\mathrm{A} 13$, where the $\mathrm{pH}$ range is $6.8-7.3$, or in the other studied wells (Table 2 ). The $\mathrm{pH}$ is 433 probably buffered by calcite dissolution from Chalk, which explains the high Ca contents of 
434 wells $\mathrm{A} 12, \mathrm{~A} 13, \mathrm{~A} 14$ and A15 compared to the other Les Ansereuilles wells (Cary et al., 435 2014; Table 2). The production of $\mathrm{HCO}_{3}{ }^{-}$according to Equation 2 can contribute to the 436 relatively high content observed in the studied groundwater. Better to assess the $\mathrm{HCO}_{3}$ 437 origin, the $\delta^{13} \mathrm{C}$ of dissolved inorganic carbon was measured on some samples, ranging from $-14.20 \%$ to $-11.6 \%$ with a $\mathrm{pH}$ ranging from 6.73 to 7.1 . These values are typical of the Chalk aquifer in unconfined or semi-confined conditions, and are interpreted as resulting from dissolution of the carbonate matrix (Kloppmann et al., 1998). The concentrations of dissolved manganese increase in groundwater along the transect $A 16$ to $A 15$, with a maximum in well A12. Dissolved iron concentrations follow the same trend with a general increase reaching the highest values in well $\mathrm{A} 14 . \mathrm{Mn}$ - and Fe-oxihydroxides reduction is most probably the main process here. The presence of dissolved methane in wells A12-A13-A15 (Table 3) confirms that organic matter is probably first biologically or chemically degraded in $\mathrm{CO}_{2}$, and then reduced by $\mathrm{CH}_{4}$, although the measured redox potential does not represent a $\mathrm{CH}_{4} / \mathrm{CO}_{2}$ couple or a very reductive system.

The continuum of wells shows high $\mathrm{SO}_{4}{ }^{2-}$ values associated with high $\mathrm{Se}$ values and low $\mathrm{NO}_{3}$ values (Fig. 3). However, such high Se concentrations are not coherent with the local reductive conditions, so we suspect another process than reduction to be active here as well. An oxidation reaction may be the main process here; a very interesting element of this 452 redox sequence is that an oxidative flow crosses a progressively settled anoxic state. Indeed, 453 the monthly monitoring of well $\mathrm{A} 13$ showed dissolved $\mathrm{O}_{2}$ content varying with time from 2.5 to $4.8 \mathrm{mg} \mathrm{L}^{-1}$, these values being higher than those in wells $\mathrm{A} 12$ or $\mathrm{A} 14$ (Table 3; Fig. 4). We can thus assume that dissolved $\mathrm{O}_{2}$ is probably introduced in the system by water flowing 456 through the fractured corridor near A13 (Fig. 2). The introduction of dissolved $\mathrm{O}_{2}$ 457 superimposes a secondary "oxidation sequence" on the predominant reduction reactions. 458 Such oxidation reactions laterally are effective over short distances, governed by flow 459 direction and groundwater mixing, and by the reaction rates, as illustrated by the low 460 dissolved $\mathrm{O}_{2}$ content in wells $\mathrm{A} 12$ and $\mathrm{A} 14$ (Table 2; Fig. 4). The slight decrease of dissolved 
461 iron in well A13, mainly as Fe(II), can be linked to the presence of dissolved oxygen causing 462 Fe(III)-oxide precipitation (Fig. 4), even if chemical Fe(II) oxidation can also occur under 463 anaerobic conditions in the presence of $\mathrm{Mn}(\mathrm{IV}), \mathrm{NO}_{3}^{-}$, and $\mathrm{NO}_{2}^{-}$(Kappler and Straub, 2005). 464 Illustrated by the slight decrease in dissolved Fe- and $\mathrm{Mn}$ concentrations, the best 465 expression of oxidation are the high values of $\mathrm{SO}_{4}{ }^{2-}$ and $\mathrm{Se}$ concentrations, mainly as $\mathrm{Se}(\mathrm{VI})$, 466 in well $A 12$ (Fig. 4). The presence of a certain amount of dissolved $\mathrm{O}_{2}$ in $\mathrm{A} 13$ makes pyrite 467 oxidation possible (Eq. 4), present in reducing environments and commonly identified in 468 Chalk porosity (Edmunds et al., 1987). It also leads to the presence of $\mathrm{Fe}^{2+}$ (Eqs 4 and 5) 469 further oxidized into $\mathrm{Fe}(\mathrm{III})$, and $\mathrm{NO}_{3}{ }^{-}$reduction (Eq. 6) resulting in the high $\mathrm{SO}_{4}{ }^{2-}$ 470 concentrations of wells A13 and A12, and in denitrification (Zhang et al., 2012).

471

472

473

474

475 476

$$
\begin{gathered}
\mathrm{FeS}_{2}+\frac{7}{2} \mathrm{O}_{2}+\mathrm{H}_{2} \mathrm{O} \rightarrow 2 \mathrm{SO}_{4}^{2-}+\mathrm{Fe}^{2+}+2 \mathrm{H}^{+}(\text {Eq. } 4) \\
\mathrm{FeS}_{2}+14 \mathrm{Fe}^{3+}+8 \mathrm{H}_{2} \mathrm{O} \rightarrow 2 \mathrm{SO}_{4}^{2-}+15 \mathrm{Fe}^{2+}+16 \mathrm{H}^{+}(\mathrm{Eq} 5) \\
5 \mathrm{FeS}_{2}+14 \mathrm{NO}_{3}^{-}+4 \mathrm{H}^{+} \rightarrow 10 \mathrm{SO}_{4}^{2-}+5 \mathrm{Fe}^{2+}+7 \mathrm{~N}_{2(\mathrm{~g})}+2 \mathrm{H}_{2} \mathrm{O} \text { (Eq. 6) }
\end{gathered}
$$

$\mathrm{SO}_{3}{ }^{2-}$, a product of pyrite oxidation found in well $\mathrm{A} 14$ at low levels, is not stable and rapidly oxidizes to sulphate in the presence of oxygen or any other oxidizing agent. Acidity produced in Eq. 4 and 5 would be buffered by calcite dissolution. 


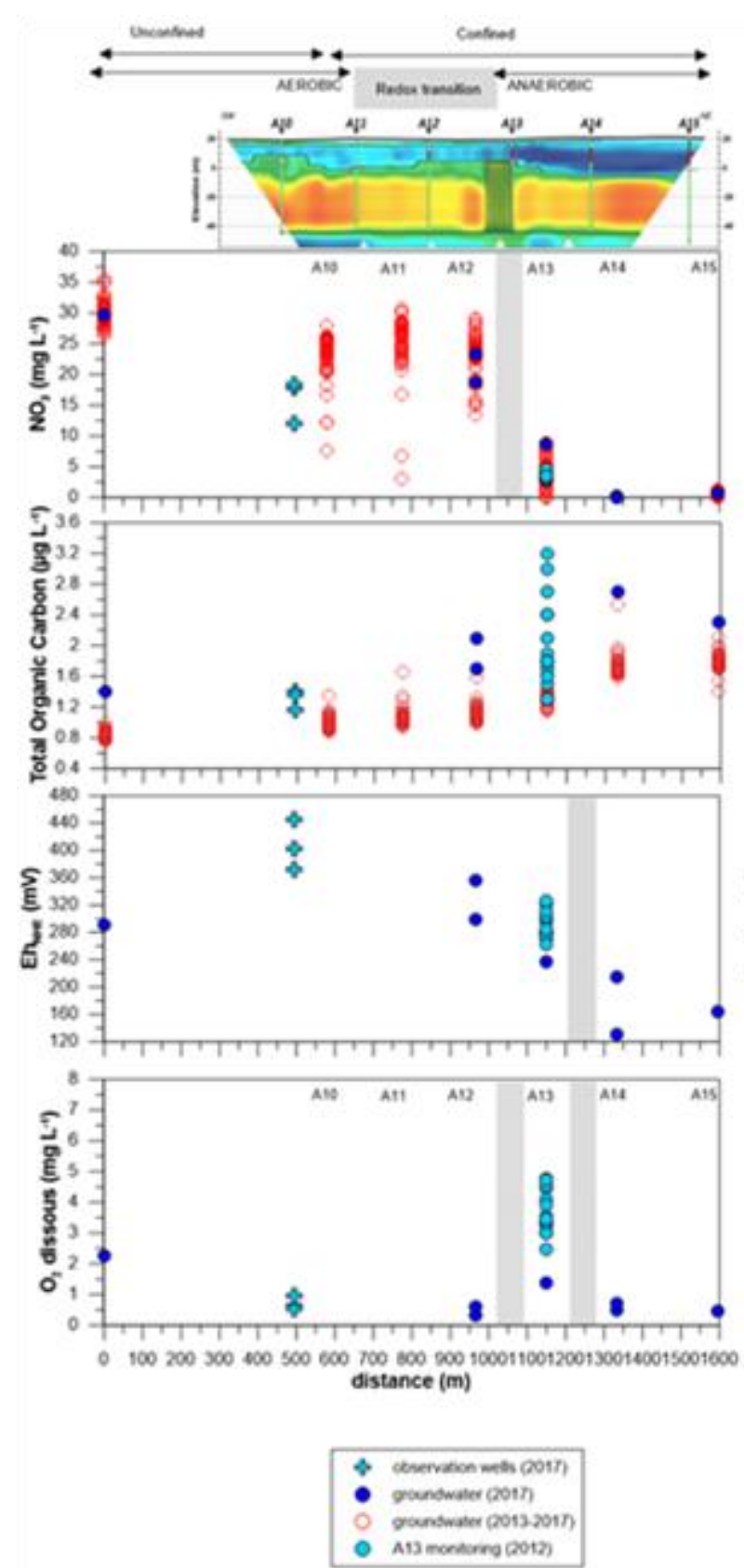

477

478

479

480

481

482

483

484

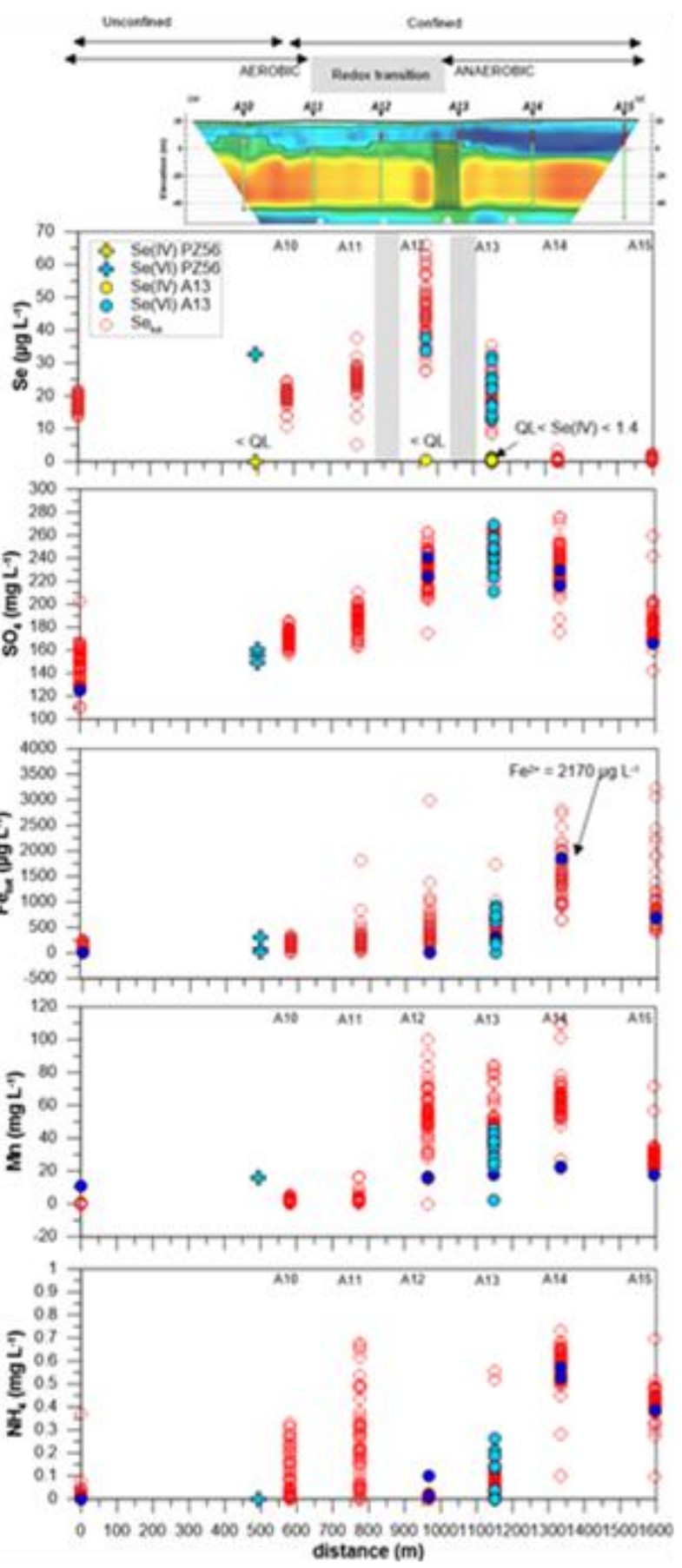

Figure 4: Redox sequence in the Les Ansereuilles field well presenting the geophysical profile and the chemical composition of groundwater in each well. Distance is calculated relative to well A10. PZ56 is not in the continuum, but slightly southeast under the same geological conditions.

It is worth noting that the processes within the water-level fluctuation zone are dynamic and that the redox front position varies with time, laterally but also vertically, in the waterlevel fluctuation zone. The oxidation processes linked to mixing with oxic waters are distributed laterally around well A13 according to the main flow driven by pumping. Towards 
well $\mathrm{A} 15$ under complete reduced conditions, $\mathrm{O}_{2}$ and $\mathrm{NO}_{3}{ }^{-}$will be rapidly reduced, whereas towards $\mathrm{A} 12$, which is not denitrified, the mixing slows down the creation of reductive conditions. This example provides an interesting illustration of the complex "permanent" transient states of groundwater.

\subsection{Constraints related to the isotopic composition of sulphate molecules} in groundwater

In the Chalk aquifer near Lille, several potential sources of dissolved sulphates can be identified. The $\delta^{34} S_{s O 4}$ in $\mathrm{E}-\mathrm{HA}$ well fields $(+0.4$ to $+1.6 \%$ ) most likely originates from atmospheric deposition and fertilizers ( -6 to $+21 \%$ ), (Vitòria et al., 2008) (Table 2). For the other groundwater samples, a large variability of negative $\delta^{34} S$ values is noticed between wells (Figs. 6 and 7), matching the general composition of pyrite (Thode, 1991), of local pyrite and local solid Chalk (respectively $\delta^{34} S_{S O 4}$ of $-20 \%$, and -10 to $15 \%$; Simon, 1986)).

The first hypothesis lies in a mixing between the E-HA pole and the T-Q end-member as defined in Cary et al. (2014), with $\delta^{34}$ S of Louvil Clays: -37 to $-40 \%$ (Bernard et al., 1981). The negative values of sedimentary sulphides in the T-Q end-member are coherent with their marine origin. In the redox sequence (Fig. 5) where only Louvil clay is present, the mixing line correctly fits values of wells A15, A26 and E-HA, but it does not explain all the points. A $\mathrm{SO}_{4}{ }^{2-}$ excess is found in well $\mathrm{A} 14$, and a deficit for PZ56 and A12. The annual variability of $\delta^{34} S$ in well $A 13$ is not completely explained; some points belong to the general area of sulphates deriving from pyrite dissolution, and other points correspond to the sulphate reduction line (Figs $6 a$ and b). As pumping induces groundwater mixing, the decreasing and variable rates of oxidized water reaching wells $A 12, A 13$ and $A 14$ through the fractures of the corridor should constrain the processes controlling $\delta^{34} \mathrm{~S}_{\mathrm{SO} 4}$ and $\mathrm{SO}_{4}$ concentrations.

The second hypothesis then must consider fractionation processes. All the wells of the redox sequence are well explained by the reduction line (slope -2 , Figs $6 a$ and $b$ ). The observed increase in $\delta^{34} \mathrm{~S}_{\mathrm{SO} 4}(+16.8 \%)$ and $\delta^{18} \mathrm{O}(+4.5 \%)$ from wells $\mathrm{A} 12$ to $\mathrm{A} 15$ is interpreted as resulting from kinetic S-isotope fractionation enhanced by bacterial sulphate 
513 reduction, causing a preferential enrichment in ${ }^{34} \mathrm{~S}$ and ${ }^{18} \mathrm{O}$ in the residual $\mathrm{SO}_{4}{ }^{2-}$. The

514 Rayleigh equation (Mariotti et al., 1988) can be used to describe isotope fractionation :

$$
\delta_{r}=\delta_{0}+\varepsilon \ln \frac{C}{C_{0}}(E q .7)
$$

516 where $\delta_{\mathrm{r}}$ and $\delta_{0}$ are residual and initial sulphate reservoirs, $\varepsilon$ is the isotopic enrichment factor

517 and $\mathrm{C} / \mathrm{C}_{0}$ is the remaining sulphate fraction. The Rayleigh equation was calculated for $\varepsilon$ -

$51830 \%$ and $-10 \%$ with the T-Q end-member as the initial source. This range of $\varepsilon$ may represent

519 a natural variability of conditions, with various rates of fractioning due to evolving redox

520 conditions and processes (Detmers et al., 2001). All points are correctly explained by the

521 range included in the two curves modelling bacterial sulphate reduction. The enrichment

522 factor of $-10 \%$ explains the composition of PZ56 and well $A 12$, whereas that of $-30 \%$ better

523 corresponds to the other wells of the sequence. This difference may be due to the fact that

524 PZ56 and well A12 are not pumped, contrary to the other wells. It is possible that alternating

525 oxidation-reduction cycles caused by pumping enhance the reduction process beyond

526 normal denitrification and Fe-oxide dissolution. We expect that this effect is less visible in the

527 non-exploited wells.

528 However, $\mathrm{SO}_{4}{ }^{2-}$ concentrations in wells A12-A13-A14 are expected to decrease with 529 increasing reducing conditions, as is the case for A15, but they do not vary significantly (Fig 530 5). This means that, although $\mathrm{SO}_{4}{ }^{2-}$ is reduced by microorganisms, this may be compensated 531 by an increase in the contribution of pyrite oxidation in wells $A 12$ and $A 13$. The low variability 532 of the $\delta^{34} S_{S O 4}$ of sulphates is observed in wells $A 13(n=13)$ and $A 12(n=2)$ data, because 533 sulphur isotopes essentially undergo no fractionation during pyrite oxidation to sulphate (Van 534 Stempvoort et al., 1994). 


\begin{tabular}{|lll|}
\hline Redox sequence (A12-A15) & Les Ansereuilles & Carboniferous groundwater \\
t A13 monitoring & گ Observation wells - Rayleigh distillation curve \\
SPZ56 & $\bigcirc$ Emmerin & - Mixing line \\
A26 & $\Delta$ Houplin-Ancoisne
\end{tabular}

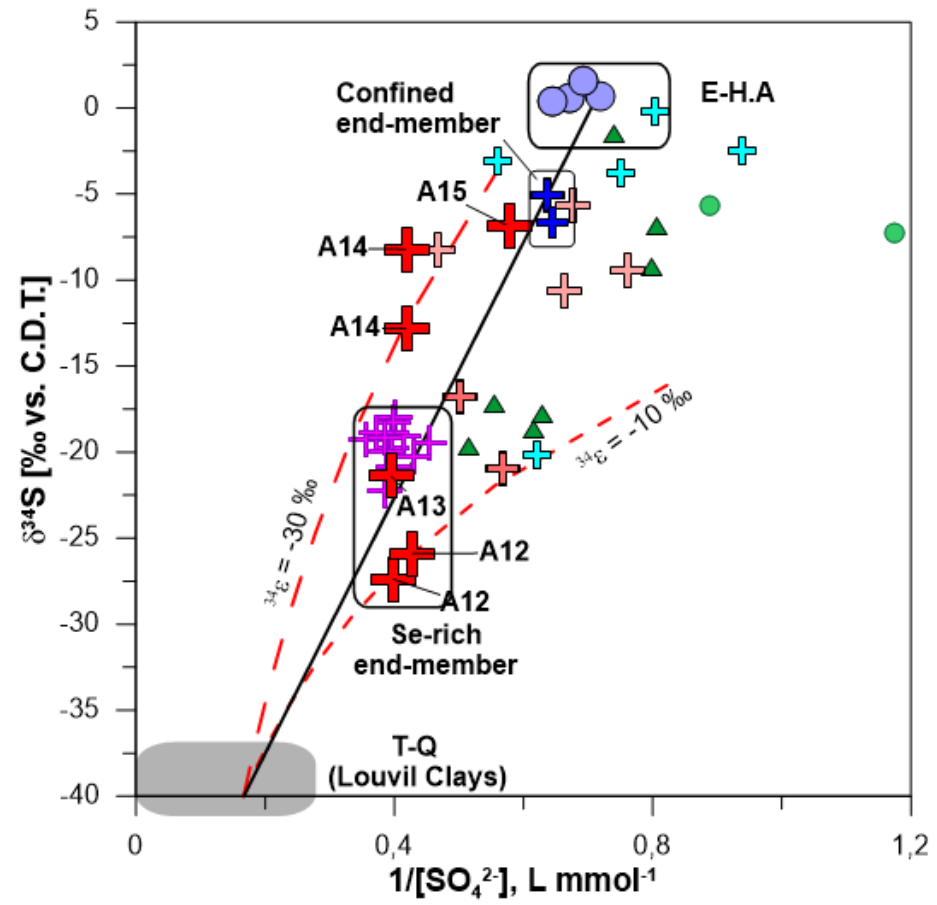

Figure 5: Variations of $\delta^{34} S$ (normalized to Vienna Canyon Diablo Troilite) of sulphate molecules in groundwaters versus $1 / \mathrm{SO}_{4}{ }^{2-}$ from the well fields of southern Lille. Data from Carboniferous groundwater are from Gourcy et al. (2013). The error bar is within the point.

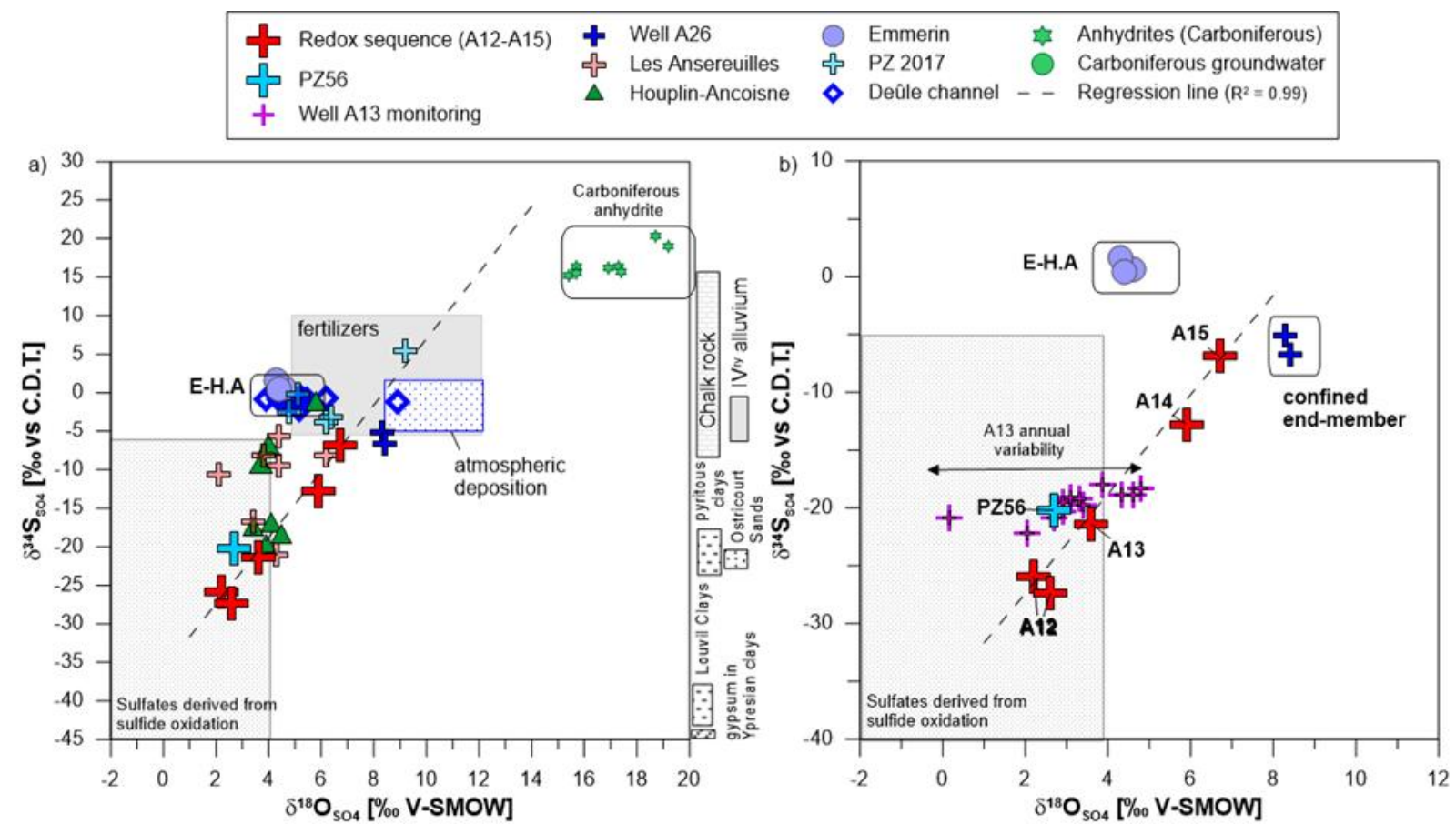

Figure 6: a) $\delta^{34} S_{S O 4} v s \delta^{18} O_{S O 4}$ in groundwater from the well fields (2011-2017) and monitoring data of well A13; b) Zoom on the redox sequence area. Bibliographic data are from (Bernard, 1979; Gourcy et 
545 In the redox sequence of Les Ansereuilles, the general scheme of Se concentrations in 546 groundwater shows Se values around $20 \mu \mathrm{g} \mathrm{L}^{-1}$ under oxic conditions that evolve to very low 547 values under progressively reducing conditions (MEL data of Fig. 4; Table 2). As expected, $548 \mathrm{Se}(\mathrm{VI})$ is the main inorganic Se form in these groundwaters, except for wells $\mathrm{A} 12$ and $\mathrm{A} 13$ 549 where low Se(IV) concentration values were detected (Fig. 4 and Table 2). This is coherent, 550 as reducing conditions promote the reduction of $\mathrm{Se}(\mathrm{VI})$ and $\mathrm{Se}(\mathrm{IV})$ ions to insoluble 551 elemental $\mathrm{Se}(0)$. In spite of this general scheme, a large increase in Se concentrations in 552 well $\mathrm{A} 12$ and, to a lesser extent, in A11 and A13, was noted (Figs. 3 and 4).

As already mentioned for the sulphur cycle, the mixing with oxidized water flowing from 554 the fracture corridor probably superimposes oxidation of reduced Se species, pyrite playing a 555 major role in controlling Se mobility and speciation. As part of the general redox sequence, 556 the creation of reducing conditions imposes simultaneous reduction of $\mathrm{NO}_{3}, \mathrm{Se}(\mathrm{VI})$ and $\mathrm{SO}_{4}{ }^{2-}$ 557 that significantly removes Se from water (Nkansah-Boadu, 2019; Oremland et al., 1999; Tan 558 et al., 2018). Precipitation of pyrite induces reduction of soluble Se(IV) and Se(VI) (Mitchell et 559 al., 2013), and Se adsorption or incorporation in the crystal lattice (Diehl et al., 2012; Naveau 560 et al., 2007). The reduction of aqueous Se(IV) by pyrite is dominated by the following 561 reaction in Equation 8 (Kang et al., 2011):

$$
5 \mathrm{FeS}_{2}+3.5 \mathrm{HSeO}_{3}^{-}+1.5 \mathrm{H}^{+} \rightarrow 2 \mathrm{SO}_{4}^{2-}+\mathrm{Fe}^{2+}+3.5 \mathrm{Se}(0)+2 \mathrm{H}_{2} \mathrm{O} \text { (Eq. 8) }
$$
reaction, leading to the formation of $\mathrm{Se}(0)$ (Liu et al., 2008). $\mathrm{Se}(0)$ can also be transformed to 565 $\mathrm{FeSe}_{2}$ (ferroselite) with the depletion of Se(IV) (Kang et al., 2016). Not detected in the Louvil Clays, perhaps because of its presence in very small amounts, $\mathrm{FeSe}_{2}$ that precipitates under 567 reducing conditions in anoxic environments (Ryser et al., 2005), may be present in the 568 water-level fluctuation area in the Chalk. Under the local oxidizing conditions induced by 569 groundwater mixing and in view of the values in the nearby Houplin-Ancoisne well field (Fig 570 3), we can assume that the oxidizing groundwater may contribute a certain amount of Se 
571 (probably around $\left.10 \mu \mathrm{g} \mathrm{L}^{-1}\right)$ and nitrate $\left(60-70 \mathrm{mg} \mathrm{L}^{-1}\right)$ from the local geochemical 572 background. Furthermore, organic matter can be degraded by aerobic heterotrophic bacteria, 573 releasing Se that was complexed with insoluble organic molecules, as illustrated by the 574 presence of organic carbon (DOC 1.7 to $2.9 \mathrm{mg} \mathrm{L}^{-1}$ ) in groundwater of well $\mathrm{A} 13$. $\mathrm{Se}$ (IV) 575 adsorption with Fe-Mn-oxide precipitation potentially is another major process (Xu et al., 576 2020).

577 The highest Se values are found with low amounts of dissolved $\mathrm{O}_{2}\left(0.5-4 \mathrm{mg} \mathrm{L}^{-1}\right)$ and 578 nitrate $\left(15-30 \mathrm{mg} \mathrm{L}^{-1}\right)$, but high $\mathrm{SO}_{4}{ }^{2-}$ values $\left(>170 \mathrm{mg} \mathrm{L}^{-1}\right.$; Fig. 3). This range of values 579 reflects the nitrate reduction area, which is accompanied by oxidation of Se-bearing pyrite 580 and of Se reduced phases produced by microorganisms during an earlier anoxic phase. 581 Indeed, Se included in sulphides—pyrite, marcasite or mackinawite—can be released during 582 their oxidation by sulpho-oxidizing bacteria. Moreover, theoretical calculations of $\mathrm{Se}^{2-}$ or $583 \mathrm{Se}(0)$ oxidation by $\mathrm{NO}_{3}{ }^{-}$and $\mathrm{O}_{2}$ show favourable Gibbs free energies for their oxidation by $584 \mathrm{NO}_{3}$, indicating that $\mathrm{NO}_{3}{ }^{-}$can act as an electron acceptor for Se oxidation (Wright, 1999). As 585 the distance to the corridor increases according to the pumping-induced flow directions, the 586 general dynamic is a decrease of oxic conditions with less intense oxidation, resulting in very 587 low $\mathrm{Se}$ and $\mathrm{NO}_{3}{ }^{-}$concentrations.

Except for the redox sequence, $\mathrm{NO}_{3}{ }^{-}$concentrations above $10 \mathrm{mg} \mathrm{L}^{-1}$ in groundwater 589 (grey circles on Fig. 3) are associated with Se concentrations limited to $20 \mu \mathrm{g} \mathrm{L}^{-1}$, which is 590 defined as the maximum natural threshold value (Fig. 3). This reflects oxic conditions, where 591 pyrite is not usually present. The decrease of Se values from 20 to $<0.5 \mu \mathrm{g} \mathrm{L}^{-1}$ corresponds to $592 \mathrm{NO}_{3}$ values from $10 \mathrm{mg} \mathrm{L}^{-1}$ to $<0.5$, which means that $\mathrm{NO}_{3}{ }^{-}$and $\mathrm{SeO}_{4}{ }^{2-}$ reduction can occur 593 simultaneously. This is coherent with bibliographic data from microbiological laboratory 594 experiments, with threshold values of $5-10 \mathrm{mg} \mathrm{L}^{-1}$ of $\mathrm{NO}_{3}^{-}$above which $\mathrm{Se}(\mathrm{VI})$ reduction is 595 inhibited (Tan et al., 2018; Thouin et al., 2019). In view of the above, pyrite plays an important role. In the Louvil Clays, it contains 7 597 to $29 \%$ of the total Se stock, $48-61 \%$ of the available stock already being associated with 598 pyritic compounds, meaning that most of the "bioavailable" Se is already trapped in these 
599 reduced sulphur compounds. We do not know the Se content of pyrite contained in Chalk, 600 but we can assume that its potential as a Se-release source or for Se-trapping is important 601 and will grow with time. Indeed, the superimposition of multi-year alternations of oxidation 602 and reduction processes has generated a large and variously crystallized pool of pyrite in the 603 Chalk porosity controlled by water-level fluctuations in the Chalk aquifer.

\subsection{Short- and long-term contaminants cycles}

605 Considering relatively short cycles at a multi-annual scale, groundwater goes through 606 transient states according to recharge, mixing with waters from the fracture corridor, and 607 pumping. This suggests that $\mathrm{Fe}, \mathrm{Mn}$ and associated trace metals $\mathrm{S}$ and Se, undergo multiple cycles of oxidation, mobilization, and re-reduction, resulting in a metal-rich redox front.

For longer cycles, we can suppose that the redox front has been migrating downward

610 since emersion of the region, and that this migration is dependent on overall changes in 611 recharge and exploitation. In the main wells of the study area, the present-day dynamic level 612 reaches its lowest depth in the Chalk aquifer and moves ever closer down to the estimated 613 non-productive zone of the aquifer, after 50 years of large $( \pm 20 \mathrm{~m})$ variations in the water614 level depth. The base of the Louvil Clays therefore remains mainly unsaturated, today.

With $-8 \%$ of precipitation and $+4 \%$ of evapotranspiration since 2016 (MeteoFrance 616 data), relative to the 1981-2010 period (Picot and Bourgine, 2010), the local climate-change 617 effect is dominated by a sharp decrease in groundwater recharge (-7\%), and over three to 618 four months instead of six, before. Although demand is growing, the official extraction rates 619 were decreased from 37 to $31 \mathrm{Mm}^{3} /$ year between 2016 and 2020, to preserve the well field 620 that has reached its maximum capacity. Under these conditions, the transfer of elements 621 from the primary Louvil Clays source probably has been notably reduced, especially for metals, Se and organic matter, which may become a limiting factor for future redox reactions. Only complete cessation of pumping would lead to a heightening of water levels, 624 creating the conditions for increasing water stocks in the Chalk. If we consider the imprints of 625 overall changes, evolution scenarios should be drawn for predicting Se speciation. Durable 
626 exploitation of the well field should stabilize water-level fluctuations and the unsaturated 627 zone. The Se-in-Chalk stock would not increase, Se mobility would be driven by pyrite 628 formation and dissolution, and bacterial reduction processes would depend on geology 629 constraints. It would thus be interesting to assess the role of Se in pyrite-formation rate, as 630 trace elements such as $\mathrm{Ni}$ or As respectively accelerate or inhibit pyrite formation (Baya et 631 al., 2021). However, a large reduction in pumping or abandonment of the well field would 632 recreate the reductive conditions for lowering Se mobility, e.g., by stocking Se in the pyrite 633 pool of the Chalk, but would also increase Se(IV) concentrations until the conditions are 634 favourable for $\mathrm{Se}(0)$ formation. To better understand the effects of global climate change on 635 the biogeochemical cycling of redox-sensitive elements, a reactive transport model (Shultz et al., 2018) could be used and coupled with the existing hydrogeological model for testing various scenarios of groundwater use.

\section{Conclusions}

639

640 The selenium cycle is affected by processes of a redox sequence, potentially leading to high 641 Se concentrations in groundwater. The spatial and temporal disparities of Se concentrations 642 in a dynamic system, are controlled by geological and hydrogeological constraints-here the 643 presence of Se-enriched Louvil Clays that progressively confine the Chalk aquifer-and by 644 variations in the water-level depth induced by recharge and pumping. Our conceptual 645 scheme presents the main reductive processes in the Les Ansereuilles succession near Lille 646 (France), and the superimposition of localized oxidation processes, mainly pyrite oxidation, 647 on the investigated Critical Zone, resulting in a Se hot spot (Fig. 7). Here, the Se-rich redox 648 front has been steadily migrating downward in the water-level fluctuation zone of the Chalk 649 aquifer.

650 Over the past years, low recharge has not compensated groundwater exploitation and 651 the recent pandemic has further increased a growing water demand. However, the pool of Se 652 in the Chalk aquifer may not increase very much in the coming years, as the base of the 
653 Louvil Clays, a Se source, will remain under unsaturated conditions. The key challenge 654 remains the mobility of the Se pool in the Chalk aquifer, linked with the presence of pyrite. 655 Concerning the other parts of the well fields, outside the redox sequence, Se mainly occurs 656 in Quaternary sediments, where the natural background concentration range is $10-20 \mu \mathrm{L} \mathrm{L}^{-1}$. 657 Increased precipitation or flooding is expected to lead to a potential change in soil redox 658 conditions, coupled with rapid input of oxygen, and possibly nitrates, into the system, as well 659 as a major impact on biogeochemical processes and Se mobility.

660 Key parameters for evaluating Se mobility under global change, are changes in nitrate 661 concentrations in groundwater and in bacterial activity in the water-level fluctuation zone. 662 Most of the well fields being in agricultural land, the challenge is to develop strategies for 663 limiting nitrate entries to improve groundwater quality. However, Se distribution and 664 speciation, which are controlled by redox reactions and biogeochemical processes, must first 665 be better assessed through considering the complete Se biogeochemical cycle, including 666 solid and organic Se forms. To fully unravel the reactivity and transfer of Se, Se isotopes 667 should be useful indicators.

668 


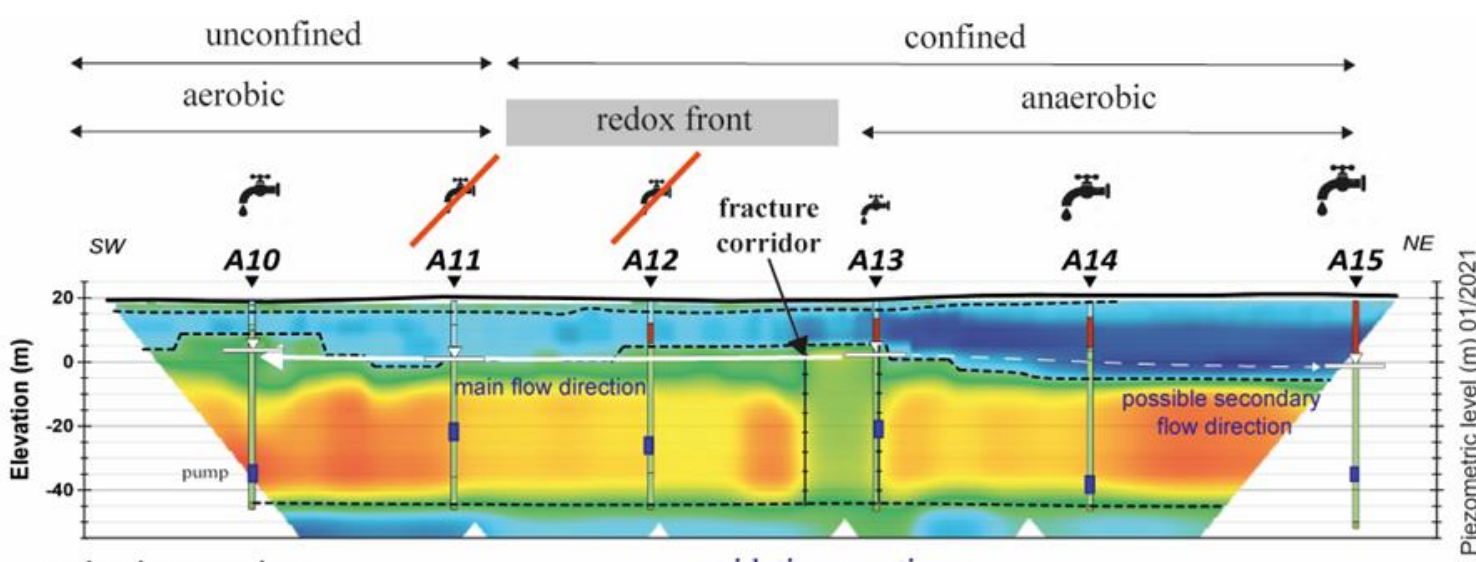
reduction reactions

oxidation reactions

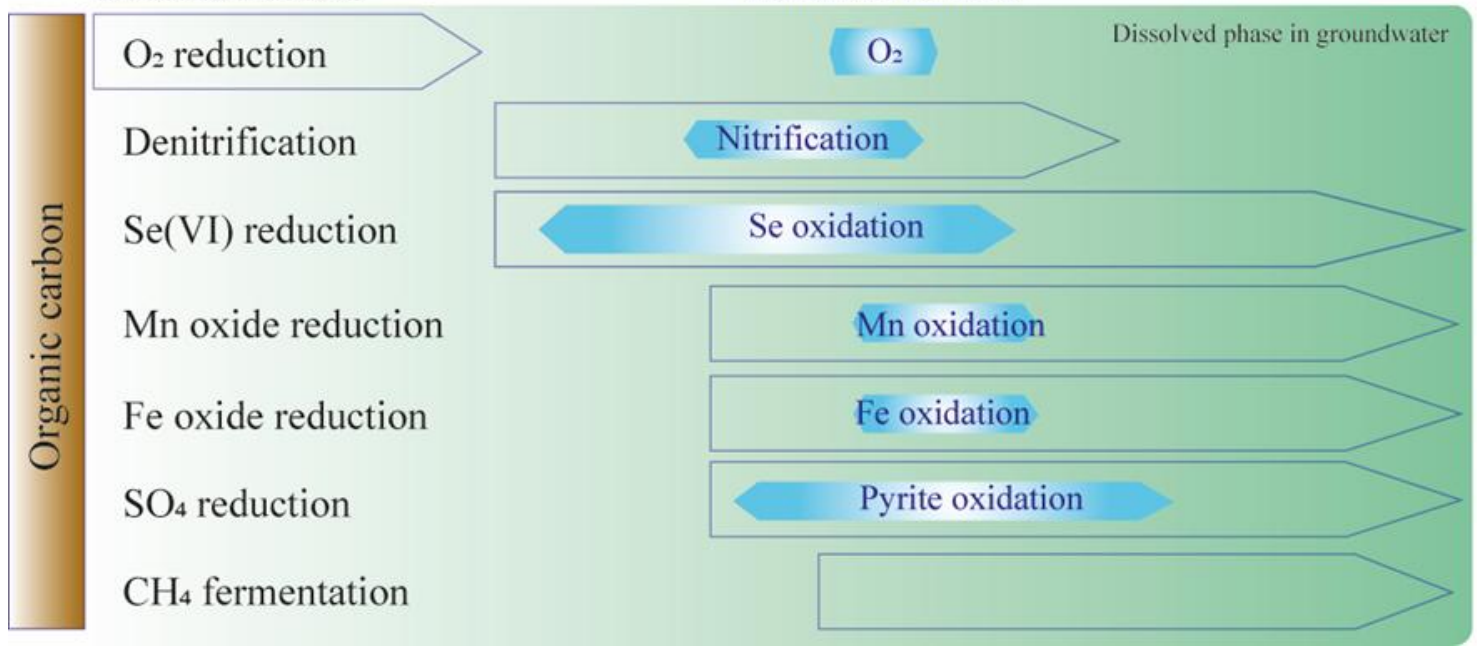

Figure 7: Lateral evolution of reductive reactions along the A10-A15 transect and local superimposition of oxidation reactions. The taps symbolize groundwater pumping rates and well closure due to high Se contents (A12 and A11). The geophysical profile shows resistivity variations, from low (blue) to high (red), and illustrates the progressive confinement of the Chalk aquifer by the Louvil Clays (in deep blue). The Chalk is divided in green (productive) and orange (less productive) parts where the pumps are now located. The main flow direction is indicated (wells A13 to A10), and also a possible secondary one (A13-A15) that may vary with pumping intensity. The large arrows symbolize reductive reactions that are laterally staggered with oxidation processes. The fracture corridor near well A13 supplies oxygenated groundwater to the reductive system by mixing, that superimposes local oxidation reactions symbolized by the blue double arrows. The reaction domains are drawn at well scale (about $200 \mathrm{~m}$ spacing). Organic carbon provides electrons to the reduction reactions.

\section{Acknowledgments}

683 This study was supported financially and technically by the Lille European Metropolis, the 684 French Geological Survey (BRGM), Eaux du Nord, Noréade, the University of Lille, and the 685 Artois-Picardie Water Agency, in the context of projects COHMET (2017-2020), Thermosel 686 (2011-2013) and Geo2020 (2020-2021). The authors thank M. Walaszek (LASIRE-BRGM), 

(SOURCEO) for their technical and scientific support during sampling and water analyses. The work benefited from the collaboration of C. Guerrot, C. Fléhoc and A.M. Gallas (BRGM Mass-Spectrometry team) who provided the $\delta^{34} \mathrm{~S}_{\mathrm{SO}}$ and $\delta^{18} \mathrm{O}_{\mathrm{SO} 4}$ isotopic analyses, and of $\mathrm{T}$. Conte (BRGM Chemistry laboratories) who provided the major- and trace-element analyses. Several ICP-AES and ICP-MS measurements were also performed on the Chevreul Institute Platform (U-Lille/CNRS). The Region Hauts de France and the French government are acknowledged for co-funding of these apparatus. We thank the landowner of the fields crossed by the geophysical profile. H.M. Kluijver edited the final English manuscript for language and content. The authors are grateful to the Editor and the two anonymous reviewers for thoughtful revisions of the manuscript and constructive comments.

\section{References}

700

701

702

703

704

705

706

707

708

709

710

711

712

713

714

Acworth, R., 1987. The development of crystalline basement aquifers in a tropical environment. Quarterly Journal of Engineering Geology and Hydrogeology, 20(4), 20(4): 265-272.

ADEME, 2007. Bilan des flux de contaminants entrant sur les sols agricoles de France métropolitaine. Bilan qualitatif de la contamination par les éléments tracés métalliques et les composés tracés organiques et application quantitative pour les éléments traces métalliques. SOGREAH. 329 p.

Ashok, V., Subrata, H., 2015. Remediation of Nitrate-Contaminated Water by Solid-Phase Denitrification Process-a Review. Environmental Science and Pollution Research, 22(11).

Bailey, R.T., 2016. Review: Selenium contamination, fate, and reactive transport in groundwater in relation to human health. Hydrogeology Journal: 1-27.

Bailey, R.T., Hunter, W.J., Gates, T.K., 2012. The Influence of Nitrate on Selenium in Irrigated Agricultural Groundwater Systems. Journal of Environmental Quality, 41(3): 783-792.

Baize, D., Douay, F., Villanneau, E., Bourennane, H., Sterckeman, T., Ciesielski, H., King, D., 2010. Les éléments en traces dans les sols agricoles du Nord-Pas-de-Calais, I. Étude et cartographie des teneurs des horizons de surface. Etude et Gestion des Sols, 17: 213-237.

Bajaj, M., Eiche, E., Neumann, T., Winter, J., Gallert, C., 2011. Hazardous concentrations of selenium in soil and groundwater in North-West India. Journal of Hazardous Materials, 189: 640-6.

Barron, E., Migeot, V., Rabouan, S., Potin-Gautier, M., Seby, F., Hartemann, P., Levi, Y., Legube, B., 2009. The case for re-evaluating the upper limit value for selenium in drinking water in Europe. Journal of Water and Health, 7(4): 630-641. 
Baya, C., Le Pape, P., Baptiste, B., Brest, J., Landrot, G., Elkaim, E., Noël, V., Blanchard, M., Ona-Nguema, G., Juillot, F., Morin, G., 2021. Influence of trace level As or Ni on pyrite formation kinetics at low temperature. Geochimica et Cosmochimica Acta, 300: 333-353.

Beisner, K., Naftz, D.L., Johnson, W.P., Diaz, X., 2009. Selenium and trace element mobility affected by periodic displacement of stratification in the Great Salt Lake, Utah. STOTEN, 407(19): 5263-5273.

Belle, P., Lachassagne, P., Mathieu, F., Barbet, C., Brisset, N., Gourry, J.-C., 2019. Characterization and location of the laminated layer within hard rock weathering profiles from electrical resistivity tomography: implications for water well siting. Geological Society, London, 479(1): 187205.

Bernard, D., 1979. Contribution à l'étude hydrogéochimique de la nappe de la craie dans le nord de la France. BRGM/79-SGN-245-NPC, Université des sciences et techniques de Lille, Lille.

Bernard, D., Bosch, B., Caulier, P., 1981. Acquisition et rassemblement des données géothermiques disponibles et nouvelles dans la zone Franco-Belge de Saint-Ghislain à Saint-Amand-les-Eaux (Nord).

Bessière, H., Picot, J., Picot, G., Parmentier, M., 2015. Affinement du modèle hydrogéologique de la craie du Nord-Pas-de-Calais autour des champs captants de la métropole lilloise. BRGM/RP-63689-FR.

Borch, T., Kretzschmar, R., Kappler, A., Cappellen, P.V., Ginder-Vogel, M., Voegelin, A., Campbell, K., 2010. Biogeochemical Redox Processes and their Impact on Contaminant Dynamics. Environmental Science \& Technology, 44(1): 15-23.

Brenot, A., Baran, N., Petelet-Giraud, E., Négrel, P., 2008. Interaction between different water bodies in a small catchment in the Paris basin (Brévilles, France): Tracing of multiple $\mathrm{Sr}$ sources through $\mathrm{Sr}$ isotopes coupled with $\mathrm{Mg} / \mathrm{Sr}$ and $\mathrm{Ca} / \mathrm{Sr}$ ratios. Applied Geochemistry, 23(1): 58-75.

Breynaert, E.C., Bruggeman, C., Maes, A., 2008. XANES-EXAFS analysis of Se solid-phase reaction products formed upon contacting $\mathrm{Se}(\mathrm{IV})$ with FeS2 and FeS Environ. Sci. Technol., 42: 3585-3601.

Brozmanová, J., Mániková, D., Vlčková, V., Chovanec, M., 2010. Selenium: a double-edged sword for defense and offence in cancer. Archives of Toxicology, 84(12): 919-938.

Cary, L., Benabderraziq, H., Elkhattabi, J., Gourcy, L., Parmentier, M., Picot, J., Khaska, M., Laurent, A., Négrel, P., 2014. Tracking selenium in the Chalk aquifer of northern France: Sr isotope constraints. Applied Geochemistry, 48(0): 70-82.

Chasteen, T.G., Bentley, R., 2003. Biomethylation of selenium and tellurium: Microorganisms and plants. Chemical Reviews, 103(1): 1-25.

Comte, J.-C., Cassidy, R., Nitsche, J., Ofterdinger, U., Pilatova, K., Flynn, R., 2012. The typology of Irish hard-rock aquifers based on an integrated hydrogeological and geophysical approach. Hydrogeology Journal, 20(8): 1569-1588. 
Coppin, F., Chabroullet, C., Martin-Garin, A., 2009. Selenite interactions with some particulate organic and mineral fractions isolated from a natural grassland soil. European Journal of Soil Science, 60(3): 369-376.

Darcheville, O., Février, L., Haichar, F.Z., Berge, O., Martin-Garin, A., Renault, P., 2008. Aqueous, solid and gaseous partitioning of selenium in an oxic sandy soil under different microbiological states. Journal of Environmental Radioactivity, 99(6): 981992.

De Temmerman, L., Waegeneers, N., Thiry, C., Du Laing, G., Tack, F., Ruttens, A., 2014. Selenium content of Belgian cultivated soils and its uptake by field crops and vegetables. Science of The Total Environment, 468-469(0): 77-82.

Descloitres, M., Ruiz, L., Sekhar, M., Legchenko, A., Braun, J.-J., Mohan Kumar, M.S., Subramanian, S., 2008. Characterization of seasonal local recharge using electrical resistivity tomography and magnetic resonance sounding. Hydrological Processes, 22(3): 384-394.

Desoignies, J., Sangnier, P., 1968. Notice de la carte géologique de la France au 1/50 000 de Carvin (n²0) et de Lille ( $\left.n^{\circ} 14\right)$. BRGM Ed.

Detmers, J., Brüchert, V., Habicht, K.S., Kuever, J., 2001. Diversity of sulfur isotope fractionations by sulfate-reducing prokaryotes. Applied and Environmental Microbiology, 67(2): 888-894.

Dhillon, K.S., Dhillon, S.K., 1991. Selenium toxicity in soils, plants and animals in some parts of Punjab, India. International Journal of Environmental Studies, 37(1-2): 15-24.

Dhillon, K.S., Dhillon, S.K., 2014. Development and mapping of seleniferous soils in northwestern India. Chemosphere, 0.

Diehl, S.F., Goldhaber, M.B., Koenig, A.E., Lowers, H.A., Ruppert, L.F., 2012. Distribution of arsenic, selenium, and other trace elements in high pyrite Appalachian coals: Evidence for multiple episodes of pyrite formation. International Journal of Coal Geology, 94(0): 238-249.

Dowdle, P.R., Oremland, R.S., 1998. Microbial oxidation of elemental selenium in soil slurries and bacterial cultures. Environ. Sci. Technol., 32: 3749-3755.

Edmunds, W.M., Cook, J.M., Darling, W.G., Kinniburgh, D.G., Miles, D.L., Bath, A.H., Morgan-Jones, M., Andrews, J.N., 1987. Baseline geochemical conditions in the Chalk aquifer, Berkshire, UK: a basis for groundwater quality management. Applied Geochemistry, 2(3): 251-274.

Edmunds, W.M., Shand, P., Hart, P., Ward, R.S., 2003. The natural (baseline) quality of groundwater: a UK pilot study. Science of The Total Environment, 310(1-3): 25-35.

Fernández-Martínez, A., Charlet, L., 2009. Selenium environmental cycling and bioavailability: a structural chemist point of view. Reviews in Environmental Science and Bio/Technology, 8(1): 81-110.

Gates, T.K., Cody, B.M., Donnelly, J.P., Herting, A.W., Bailey, R.T., Price, J.M., 2009. Assessing Selenium Contamination in the Irrigated Stream-Aquifer System of the Arkansas River, Colorado. Journal of Environmental Quality, 38(6): 2344-2356. 
Goldberg, S., Lesch, S.M., Suarez, D.L., 2007. Predicting selenite adsorption by soils using soil chemical parameters in the constant capacitance model. Geochimica et Cosmochimica Acta, 71(23): 5750-5762.

Gourcy, L., Crastes de Paulet, F., Laurent, A., 2013. Sulfur origin and influences of water level variation on $\mathrm{SO}_{4}$ concentration in groundwater of the transboundary Carboniferous Limestone Aquifer (Belgium, France). Procedia Earth and Planetary Science, $7(0)$ : 309-312.

Gourcy, L., Lions, J., Wyns, R., Dictor, M., Brenot, A., Crouzet, C., Ghestem, J., 2011. Origine du sélénium et compréhension des processus dans les eaux du bassin Seine-Normandie. Rapport final. BRGM/RP-59445-FR, 178 p.

Herbel, M.J., Blum, J.S., Oremland, R.S., Borglin, S.E., 2003. Reduction of Elemental Selenium to Selenide: Experiments with Anoxic Sediments and Bacteria that Respire Se-Oxyanions. Geomicrobiology Journal, 20(6): 587-602.

Huerta-Diaz, M.A., Morse, J.W., 1990. A quantitative method for determination of trace metal concentrations in sedimentary pyrite. Marine Chemistry, 29: 119-144.

Huggett, J.M., Knox, R.W.O.B., 2006. Clay mineralogy of the Tertiary onshore and offshore strata of the British Isles. Clay Minerals, 41(1): 5-46.

Kang, M., Bardelli, F., Ma, B., Charlet, L., Chen, F., Yang, Y., 2016. The influence of pH and reaction time on the formation of $\mathrm{FeSe} 2$ upon selenite reduction by nano-sized pyritegreigite. Radiochimica Acta, 104(9): 649-656.

Kang, M., Chen, F., Wu, S., Yang, Y., Bruggeman, C., Charlet, L., 2011. Effect of pH on Aqueous Se(IV) Reduction by Pyrite. Environmental Science \& Technology, 45(7): 2704-2710.

Kappler, A., Straub, K.L., 2005. Geomicrobiological Cycling of Iron. Reviews in Mineralogy and Geochemistry, 59(1): 85-108.

Kloppmann, W., Dever, L., Edmunds, W.M., 1998. Residence time of Chalk groundwaters in the Paris Basin and the North German Basin: a geochemical approach. Applied Geochemistry, 13(5): 593-606.

Kulp, T.R., Pratt, L.M., 2004. Speciation and weathering of selenium in upper Cretaceous chalk and shale from South Dakota and Wyoming, USA. Geochimica Cosmochimica Acta, 68(18): 3687-3701.

Liu, X., Fattahi, M., Montavon, G., Grambow, B., 2008. Selenide retention onto pyrite under reducing conditions. Radiochimica Acta, 96(8): 473-479.

Liu, Y.T., Chen, T.Y., Mackebee, W.G., Ruhl, L., Vengosh, A., Hsu-Kim, H., 2013. Selenium speciation in coal ash spilled at the Tennessee Valley Authority Kingston Site. Environmental Science \& Technology, 47(24): 14001-14009.

Loke, M.H., 2015. Tutorial: 2-D and 3-D electrical imaging surveys. Geotomo Softw. Malaysia 127.

Loke, M.H., 2020. RES2DINVx64 ver. 4.10. Geotomo Softw. SDN BHD - Aarrhus GeoSoftware. 
Mariotti, A., Landreau, A., Simon, B., 1988. 15N isotope biogeochemistry and natural denitrification process in groundwater: Application to the chalk aquifer of northern France. Geochimica et Cosmochimica Acta, 52(7): 1869-1878.

Masscheleyn, P.H., Delaune, R.D., Patrick, W.H., 1991. Biogeochemical behavior of selenium in anoxic soils and sediments: An equilibrium thermodynamics approach. Journal of Environmental Science and Health. Part A: Environmental Science and Engineering and Toxicology, 26(4): 555-573.

Mast, M.A., Mills, T.J., Paschke, S.S., Keith, G., Linard, J.I., 2014. Mobilization of selenium from the Mancos Shale and associated soils in the lower Uncompahgre River Basin, Colorado. Applied Geochemistry, 48: 16-27.

Meire, B., Portal, A., Jacob, T., Paquet, F., Bitri, A., Mathieu, F., David, P.-Y., 2019. Fonctionnement de l'hydro-système, interactions et cheminements des eaux naturelles et de la n-nitrosomorpholine dans le secteur de la Faille de Lillebonne Fécamp (76) - Volet géologique et géophysique. Rapport final. BRGM/RP-67087-FR.

Mitchell, K., Couture, R.-M., Johnson, T.M., Mason, P.R.D., Van Cappellen, P., 2013. Selenium sorption and isotope fractionation: Iron(III) oxides versus iron(II) sulfides. Chemical Geology, 342(0): 21-28.

Mitchell, K., Mason, P.R.D., Van Cappellen, P., Johnson, T.M., Gill, B.C., Owens, J.D., Diaz, J., Ingall, E.D., Reichart, G.-J., Lyons, T.W., 2012. Selenium as paleo-oceanographic proxy: A first assessment. Geochimica et Cosmochimica Acta, 89: 302-317.

Naveau, A., Monteil-Rivera, F., Guillon, E., Dumonceau, J., 2007. Interactions of aqueous selenium (-II) and (IV) with metallic sulfide surfaces. Environmental Science \& Technology, 41(15): 5376-5382.

Neal, R.H., Sposito, G., 1989. Selenate Adsorption on Alluvial Soils. Soil Science Society of America Journal, 53(1): 70-74.

Négrel, P., Petelet-Giraud, E., 2005. Strontium isotopes as tracers of groundwater-induced floods: the Somme case study (France). Journal of Hydrology, 305(1-4): 99-119.

Nkansah-Boadu, F., 2019. Removal of Soluble Selenium in the Presence of Nitrate from Coal Mining-Influenced Water.

Ohlendorf, H.M., Santolo, G.M., 1994. Kesterson reservoir. Past, present, and future: An ecological risk assessment. In: Frankenberger, W.T., Benson, S. (Eds.), Selenium in the environment. Dekker, Marcel., New York, pp. 69-117.

Oremland, R.S., Blum, J.S., Bindi, A.B., Dowdle, P.R., Herbel, M., Stolz, J.F., 1999. Simultaneous reduction of nitrate and selenate by cell suspensions of seleniumrespiring bacteria. Applied and Environmental Microbiology, 65(10): 4385-4392.

Oremland, R.S., Hollibaugh, J.T., Maest, A.S., Presser, T.S., Miller, L.G., Culbertson, C.W., 1989. Selenate reduction to elemental selenium by anaerobic bacteria in sediments and culture: biogeochemical significance of a novel, sulfate-independent respiration. Appl Environ Microbiol, 55(9): 2333-2343.

Parmentier, M., Ollivier, P., Joulian, C., Albrecht, A., Hadi, J., Greneche, J.-M., Pauwels, H., 2014. Enhanced heterotrophic denitrification in clay media: The role of mineral electron donors. Chemical Geology, 390: 87-99. 
Parnell, J., Brolly, C., Spinks, S., Bowden, S., 2016. Selenium enrichment in Carboniferous Shales, Britain and Ireland: Problem or opportunity for shale gas extraction? Applied Geochemistry, 66: 82-87.

Peters, G.M., Maher, W.A., Barford, J.P., Gomes, V.G., 1997. Selenium Associations in Estuarine Sediments: Redox Effects. In: Evans, R.D., Wisniewski, J., Wisniewski, J.R. (Eds.), The Interactions Between Sediments and Water: Proceedings of the 7th International Symposium, Baveno, Italy 22-25 September 1996. Springer Netherlands, Dordrecht, pp. 275-282.

Picot, J., Bourgine, B., 2010. Modélisation géologique de la craie céno-turonienne en région Nord-Pas-de-Calais. Rapport final.

Portal, A., Jacob, T., Meire, B., Bretaudeau, F., Mathieu, F., Paquet, F., David, P.-Y., 2020. Modèle mathématique de gestion de l'hydro-système Seine - craie - alluvions sur les territoires de la Métropole de Rouen Normandie et du syndicat mixte du SAGE CaillyAubette-Robec. Rapport $n^{\circ} 2$ : Résultats des investigations géophysiques. Rapport final.

Rayman, M.P., 2000. The importance of selenium to human health. Lancet 356: 233-241.

Revil, A., Karaoulis, M., Johnson, T., Kemna, A., 2012. Review: Some low-frequency electrical methods for subsurface characterization and monitoring in hydrogeology. Hydrogeology Journal, 20: 617-658.

Ryser, A.L., Strawn, D.G., Marcus, M.A., Johnson-Maynard, J.L., Gunter, M.E., Möller, G., 2005. Micro-spectroscopic investigation of selenium-bearing minerals from the Western US Phosphate Resource Area. Geochemical transactions, 6(1): 1-1.

Schellenger, A.E., Larese-Casanova, P., 2013. Oxygen isotope indicators of selenate reaction with $\mathrm{Fe}(\mathrm{II})$ and $\mathrm{Fe}(\mathrm{III})$ hydroxides. Environ Sci Technol, 47(12): 6254-62.

Séby, F., Potin Gautier, M., Lespés, G., Astruc, M., 1997. Selenium speciation in soils after alkaline extraction. Science of The Total Environment, 207(2-3): 81-90.

Sharma, V., McDonald, T., Sohn, M., Anquandah, G., Maurizio, P., Zboril, R., 2014. Biogeochemistry of selenium. A review. Environmental Chemistry Letters, 13: 49-58.

Shultz, C.D., Gates, T.K., Bailey, R.T., 2018. Evaluating best management practices to lower selenium and nitrate in groundwater and streams in an irrigated river valley using a calibrated fate and reactive transport model. Journal of Hydrology, 566: 299-312.

Simon, B., 1986. Apports de la biogéochimie isotopique à la connaissance de la dénitrification dans les eaux souterraines. 86-SGN-641

Stillings, L.L., Amacher, M.C., 2010. Kinetics of selenium release in mine waste from the Meade Peak Phosphatic Shale, Phosphoria Formation, Wooley Valley, Idaho, USA. Chemical Geology, 269(1-2): 113-123.

Stumm, W., Morgan, J.J., 1996. Precipitation and dissolution. In: (Eds), J.W.S. (Ed.), Aquatic chemistry. Chemical Equilibra and Rates in Natural Waters, New York, pp. 329-424.

Tan, L.C., Nancharaiah, Y.V., van Hullebusch, E.D., Lens, P.N.L., 2018. Effect of elevated nitrate and sulfate concentrations on selenate removal by mesophilic anaerobic 
granular sludge bed reactors. Environmental Science-Water Research \& Technology, 4(2): 303-314.

Thode, H.G., 1991. Sulphur isotopes in nature and the environnment: an overview. In: H.R.Krouse and V.A. Grinenko (Ed.) Stable isotopes : Natural and anthropogenic sulphur in the Environmental. SCOPE 43, J.Wiley and Sons, Chichester, pp.1-26.

Thouin, H., Cary, L., Charron, M., Joulian, C., Klinka, T., Battaglia-Brunet, F., 2019. Occurrence of arsenic and selenium in aquifers used to produce drinking water near Orleans, France: indices of active biogeochemical processes, 24th International Symposium on Environmental Biogeochemistry, Potsdam, Germany.

Tugarova, A.V., Vetchinkina, E.P., Loshchinina, E.A., Shchelochkov, A.G., Nikitina, V.E., Kamnev, A.A., 2013. The ability of the rhizobacterium Azospirillum brasilense to reduce selenium(IV) to selenium(0). Microbiology, 82(3): 352-355.

Tuttle, M.L.W., Fahy, J.W., Elliott, J.G., Grauch, R.I., Stillings, L.L., 2014. Contaminants from Cretaceous black shale: II. Effect of geology, weathering, climate, and land use on salinity and selenium cycling, Mancos Shale landscapes, southwestern United States. Applied Geochemistry.

Van Stempvoort, D.R., Hendry, M.J., Schoenau, J.J., Krouse, H.R., 1994. Sources and dynamics of sulfur in weathered till, Western Glaciated Plains of North America. Chemical Geology, 111(1): 35-56.

Vinceti, M., Crespi, C.M., Bonvicini, F., Malagoli, C., Ferrante, M., Marmiroli, S., Stranges, S., 2013. The need for a reassessment of the safe upper limit of selenium in drinking water. STOTEN, 443: 633-642.

Vitòria, L., Soler, A., Canals, À., Otero, N., 2008. Environmental isotopes (N, S, C, O, D) to determine natural attenuation processes in nitrate contaminated waters: Example of Osona (NE Spain). Applied Geochemistry, 23(12): 3597-3611.

Walaszek, M., Cary, L., Billon, G., Blessing, M., Bouvet-Swialkowski, A., George, M., Criquet, J., Mossmann, J.R., 2021. Dynamics of chlorinated aliphatic hydrocarbons in the Chalk aquifer of northern France. Science of The Total Environment, 757: 143742.

Wright, W.G., 1999. Oxidation and mobilization of selenium by nitrate in irrigation drainage. Journal of Environmental Quality, 28(4): 1182-1187.

Xu, W., Zhu, J.-M., Johnson, T.M., Wang, X., Lin, Z.-Q., Tan, D., Qin, H., 2020. Selenium isotope fractionation during adsorption by $\mathrm{Fe}, \mathrm{Mn}$ and Al oxides. Geochimica et Cosmochimica Acta, 272: 121-136.

Yang, G.Q., Wang, S.Z., Zhou, R.H., Sun, S.Z., 1983. Endemic selenium intoxication of humans in China. Am J Clin Nutr, 37: 872-881.

Zhang, Y.-C., Slomp, C.P., Broers, H.P., Bostick, B., Passier, H.F., Böttcher, M.E., Omoregie, E.O., Lloyd, J.R., Polya, D.A., Van Cappellen, P., 2012. Isotopic and microbiological signatures of pyrite-driven denitrification in a sandy aquifer. Chemical Geology, 300-301(0): 123-132.

Zhang, Y.Q., Moore, J.N., 1996. Selenium fractionation and speciation in a wetland system. Environmental Science \& Technology, 30(8): 2613-2619. 
969

970 